\title{
Molecular basis of gastric cancer development and progression
}

\author{
Leizhen Zheng ${ }^{1}$, Liwei Wang ${ }^{1}$, JAffer Ajani ${ }^{1}$, and KePing XiE ${ }^{1,2}$ \\ ${ }^{1}$ Department of Gastrointestinal Medical Oncology, Unit 426, The University of Texas M.D. Anderson Cancer Center, \\ 1515 Holcombe Boulevard, Houston, TX 77030, USA \\ ${ }^{2}$ Department of Cancer Biology, The University of Texas M.D. Anderson Cancer Center, Houston, TX, USA
}

\begin{abstract}
Gastric cancer is one of the leading causes of cancer death worldwide. Because of its heterogeneity, gastric cancer has been an interesting model for studying carcinogenesis and tumorigenesis. Various genetic and molecular alterations are found in gastric cancer that underlie the malignant transformation of gastric mucosa during the multistep process of gastric cancer pathogenesis. Although the detailed mechanisms of gastric cancer development remain uncertain, the enhancement in understanding of its molecular biology in recent years has led to a better perspective on the molecular epidemiology, carcinogenesis, and pathogenesis of gastric cancer. More importantly, it is becoming possible to use molecular markers in differential diagnosis, prognostic evaluation, and specific clinical interventions. Because multiple molecular alterations are frequently noted in gastric cancer and because its histology is complex, new technologies for studying its molecular biology are important to further evaluate gastric carcinogenesis. This review describes our current knowledge of the molecular basis of gastric cancer as it relates to molecular epidemiology, multiple molecular alterations in pathogenesis, and molecular determinants of invasion and metastasis, as well as their potential clinical applications.
\end{abstract}

Key words Oncogene - Tumor suppressor gene $\cdot$ Molecular biology $\cdot$ Metastasis $\cdot$ Stomach cancer

\section{Introduction}

Although the overall incidence of gastric cancer is decreasing in almost every country, it is still a serious health problem and remains the second most common type of fatal cancer worldwide [1]. Despite the performance of extensive diagnostic and therapeutic investigations of gastric cancer, the prognosis for patients with

Offprint requests to: $\mathrm{K}$. Xie

Received: June 13, 2003 / Accepted: February 17, 2004 advanced gastric cancer remains dismal, and little improvement in survival has been achieved in recent years [2]. One reason is that gastric cancer is still too often diagnosed at an advanced stage, despite the recent studies and efforts on the identification and management of premalignant lesions [3-5]. Over the past several years, there have been many new developments in our understanding of the molecular biology of gastric carcinoma. Many studies have clearly demonstrated that multiple genetic alterations are responsible for the development and progression of gastric cancer [6-9]. It is now evident that different genetic pathways lead to diffuse- and intestinal-type gastric cancer. Alterations in specific genes that play important roles in diverse cellular functions, such as cell adhesion, signal transduction, cell differentiation, development, metastasis, DNA repair, and glycosylation changes, have been identified, although much less is known about the mixed types or rare variants of gastric carcinoma [2-9]. Molecular biology is equally important for developing diagnostic and prognostic molecular markers. Therefore, the challenge is to detect stage-specific genetic abnormalities that may result in early diagnosis and even aid in selecting therapy. This review focuses on the molecular epidemiology and pathogenesis of the major types of gastric cancer. In addition, the molecular diagnosis of and prognosis and therapeutics for gastric cancer also are discussed.

\section{Molecular epidemiology of gastric cancer}

\section{Etiology}

In recent years, research on gastric cancer has concentrated primarily on identifying environmental and genetic risk factors. Dramatic variations in the incidence of gastric cancer in different geographical areas and from one generation to the next have led to the hypothesis that the incidence of gastric cancer is 
determined largely by environmental rather than genetic factors [10]. Also, Helicobacter pylori infection is considered a risk factor for gastric cancer that may act through different mechanisms, including induction of hyperproliferation, interference with antioxidant functions, and increasing the number of reactive oxygen species and amount of nitric oxide (NO), which may be responsible for oxidative DNA damage [11]. Nevertheless, it has been suggested that $H$. pylori is a cocarcinogen in only a very small proportion of the population infected with the organism [11]. The cofactors involved in the transformation of gastric mucosa to malignancy are unknown, though. Additionally, studies indicate that a high intake of smoked, salted, and nitrated foods and carbohydrates and a low intake of fruits, vegetables, and milk significantly increase the risk of stomach cancer [12]. Other studies suggest that genetic alterations play important roles in the multistage process of gastric carcinogenesis [13]. Hereditary gastric cancer syndromes, which are associated with Ecadherin germline mutations, account for a small minority of patients with gastric cancer [14]. A multifactorial model of human gastric carcinogenesis is currently accepted; different dietary and nondietary factors and genetic susceptibility are involved in this carcinogenesis [13].

\section{Genetic predisposition}

There is increasing interest in genetic polymorphisms as causes for gastric cancer, probably due to advances in DNA-analysis technologies [15]. Individual variations in cancer risk have been associated with specific variant alleles of different genes (polymorphisms) that are present in a significant proportion of the normal population. Polymorphisms in a wide variety of genes may modify the effect of environment $[13,16]$; these geneenvironmental interactions may explain the high variation in the incidence of gastric cancer around the world [17]. However, the interaction between environmental factors and genetic susceptibility, at least regarding the metabolic genes, such as GSTM1, GSTT1, NAT1, $N A T 2$, and $C Y P 2 E$, has not been adequately addressed [18]. Most of these studies have addressed the effect of genetic variants of metabolic enzymes and inflammation mediators. These variants have since been better characterized, and their association with cancer risk is plausible. The most widely studied polymorphism is the GSTM1-null allele. However, only a few studies have evaluated the risk of gastric cancer associated with genes that may cause mucosal protection [15], oxidative damage [19], DNA methylation [20], and DNA repair [21]. The most common result is the increased gastric cancer risk associated with the $I L 1 B$ and NAT1 variants [15,22-24]. The finding that interleukin-1 (IL-1) gene cluster haplotypes (IL1B-31T and $\left.I L 1 R N^{* 2} 2 * 2\right)$, which are thought to increase IL-1 production and inhibition of gastric acid secretion, are associated with an increased risk of both chronic hypochlorhydria and gastric cancer [15] supports the hypothesis that the intensity and maintenance of the inflammatory response to $H$. pylori infection may be relevant to early stages of gastric tumorigenesis [25]. Individual differences in xenobiotic transformation are also important. The observed relationship between fast acetylators (NAT1*10) and increased gastric cancer risk supports a role in procarcinogen activation in human gastric cancer [23,24].

However, most of the studies of the role of genetic polymorphisms and gastric cancer risk have provided inconsistent results. The disparity in the findings of epidemiological studies may result from limitations in design, the presence of confounding factors, and potential sources of bias that may have significantly affected the conclusions. The limitations of the published literature include potential selection bias for both cases and controls, a limited number of cases without statistical power sufficient to evaluate the gene-environmental interactions [13], mixed cases with different histological types, and anatomic locations that may have different etiologies and genetic predispositions [13].

In summary, major progress has been achieved in the understanding of the etiopathogenesis of sporadic gastric cancer. Clearly, certain environmental and genetic factors contribute to an increased risk of developing gastric cancer. On the other hand, recent studies have also shown that the familial aggregation of gastric cancers relates to numerous factors, including familial clustering of $H$. pylori infection in families, high prevalence of hypochlorhydia and atrophy in infected individuals, other genetic and molecular changes in gastric mucosa that are independent of $H$. pylori infection, and, more importantly, hereditary gastric cancer due to germline mutation of the E-cadherin gene. These discoveries make it possible and important to carry out genetic counseling and testing of asymptomatic family members, and even preventive gastrectomy (for details, see recent review article by Ebert et al. [2].

\section{Molecular genetics of gastric cancer}

Although the pathogenesis of gastric cancer remains largely unclear, the rapid progress in elucidating the molecular biology of cancer has increasingly provided evidence that transformation of a normal epithelial cell to a malignant cell is a multistep process and results from accumulation of multiple gene abnormalities $[10,26]$. Correa [26] has postulated that a sequence of histomorphological changes leads to gastric cancer. 
According to this model, after the development of chronic gastritis, atrophy, intestinal metaplasia, and eventually dysplasia will develop, followed by gastric cancer [26]. This model is still open to debate, and it remains unclear whether these changes follow each other step by step, or whether some histomorphological changes directly precede gastric cancer development [27]. In addition, other authors have interpreted these steps as histomorphological changes that carry an increased risk of gastric cancer [28-31].

A number of molecular abnormalities have been identified, including microsatellite instability (MSI), inactivation of tumor suppressor genes, activation of oncogenes, and reactivation of telomerase [26,27]. Although cancers may harbor multiple molecular alterations, they may not be specific for gastric cancers. Thus, the identified abnormalities may represent only the pathogenesis of gastric cancer, and they have not been identified as a specific sequence of changes leading to gastric carcinoma [6].

\section{$M S I$}

MSI is defined as the presence of replication errors in simple repetitive microsatellite sequences due to DNA mismatch repair deficiency. It is classified as highfrequency (MSI-H), low-frequency (MSI-L), or stable (MSS) [28]. MSI has been recognized as one of the earliest changes in carcinogenesis and results in genomic instability [32]. MSI is present in a subset of gastric cancers [33], ranging from $13 \%$ to $44 \%$ of gastric tumors [9]; in particular, MSI-H occurs in $10 \%$ to $16 \%$ of gastric cancers [9]. Furthermore, hypermethylation of $\mathrm{CpG}$ islands in the promoter region of the $h M L H 1$ gene is associated with decreased hMLH1 protein expression and often occurs in gastric cancer cases with MSI-H, indicating that epigenetic inactivation of this gene in association with promoter methylation may underlie MSI [34]. MSI in gastric cancer cases is also associated with antral tumor location, intestinal-type differentiation, and a better prognosis [6,9]. Such cancer cases exhibit a different genetic background from those without MSI, i.e., they exhibit mutations of transforming growth factor (TGF) receptor II and do not have p53 mutations [35]. MSI-H-positive gastric cancers are clinicopathologically distinct; thus, it may be valuable to identify subgroups of gastric cancers [36]. The MSI technique is promising for the early detection of cancer: rather than searching for a specific gene, it may be used as a screening tool [10]. Additional genes with simple, tandem repeat sequences within their coding regions that have been found to be specifically altered in gastric cancers displaying MSI include $B A X, h M S H 3, h M S H 6$, $E 2 F-4$, TGF- $\beta$ receptor II, and insulin-like growth factor receptor II, which are known to be involved in the regulation of cell-cycle progression and apoptotic signaling $[8,9]$.

\section{Inactivation of tumor suppressor genes}

Inactivation of tumor suppressor genes due to mutations and/or loss of heterozygosity ( $\mathrm{LOH}$ ) is also a frequent event in gastric carcinogenesis. For example, inactivation of p53 and p16 has been reported in both diffuse- and intestinal-type gastric cancers, whereas adenomatous polyposis coli $(A P C)$ gene mutations seem to occur more frequently in intestinal-type gastric cancers [37-39]. Other candidate tumor suppressor genes that have exhibited genomic alterations in gastric cancers include fragile histidine triad (FHIT) and deleted in colon cancer $(D C C)$.

Mutation or $\mathrm{LOH}$ of the $p 53$ gene has been reported in up to $80 \%$ of gastric cancer cases independent of the histological subtype, and predominately in cases of metastatic disease [39,40-42]. However, p53 mutations have also been identified in early dysplastic and metaplastic lesions (about 10\%) [37,43,44], and some studies have reported that $p 53$ alterations have a crucial role in early intestinal-type gastric carcinogenesis, likely acting at the transition step between metaplasia and dysplasia, and that the alterations are mainly associated with tumor progression in diffuse-type cancer [37]. However, because of the use of different techniques, including immunohistochemistry, polymerase chain reaction single-strand conformation polymorphism, and sequencing, the results are not consistent [45].

Up to $60 \%$ of intestinal-type gastric tumors and approximately $25 \%$ of adenomas have mutation and/or $\mathrm{LOH}$ of the tumor suppressor gene $A P C$ [46-50]. These alterations are rare in diffuse-type carcinomas but may be associated with signet-ring cell carcinomas [51]. However, a recent study indicated that somatic mutation of the $A P C$ gene plays an important role in the pathogenesis of gastric adenoma and dysplasia, but has a limited role in the progression of it to adenocarcinoma [52]. In addition, the APC protein is important for the degradation of $\beta$-catenin [53,54]. Specifically, it binds to $\beta$-catenin, whose free concentration within the cell is tightly regulated and kept at a low level. After interaction with the transcription factor lymphoid enhancer factor-1 (LEF-1), $\beta$-catenin translocates into the nucleus, where it regulates gene expression [55]. $\beta$ Catenin mutations have also been detected in intestinaltype gastric tumors, but are absent from diffuse-type tumors [56,57]. In intestinal-type gastric cancers, the accumulation of $\beta$-catenin protein may result from impaired degradation of the $\beta$-catenin protein due to alterations of the $\beta$-catenin and APC genes [6]. Both APC and $\beta$-catenin are members of the so-called $\mathrm{Wnt} /$ wingless signal transduction pathway, which is altered in 
more than $90 \%$ of colon cancer cases and is currently being intensively analyzed to find small molecules that selectively interfere with its activation in tumor cells.

In previous studies, $\mathrm{P}^{1} 6^{\mathrm{INK}} 4$ somatic mutations with $\mathrm{LOH}$ were noted in several cases of esophageal cancer, but not in those of gastric carcinoma [58,59]. In addition, loss of p16 expression was found to lead to abnormal hypermethylation of the $\mathrm{p} 16^{\mathrm{INK} 4}$ promoter, suggesting that this epigenetic gene expression silencing may play a role in esophageal tumorigenesis [60]. On the other hand, a significant portion $(>40 \%)$ of gastric cancers exhibited $\mathrm{CpG}$ island methylation of the promoter region of p16 [61,62]. Many of these cases exhibiting hypermethylation of promoter regions displayed the MSI-H phenotype and multiple sites of methylation, including the hMLH1 promoter region [63,64], suggesting that $\mathrm{CpG}$ island hypermethylation occurs early in multistep gastric carcinogenesis.

Aberrant methylation of promoters may lead to the transcriptional silencing of various genes (e.g., Ecadherin, p16, p15, MGMT, and $h M L H 1)$ in gastric cancer [65-67]. It has been reported that approximately $40 \%$ of gastric cancers are $\mathrm{CpG}$ island methylator phenotype (CIMP) tumors, which frequently exhibit methylation of the p16 and $h M L H 1$ genes [68]. The genetic and molecular changes in these cancers are different from those in CIMP-negative cancers, suggesting an alternative pathway of gastric cancer pathogenesis. Because these changes can also be found in normal mucosa, they are probably early events in gastric carcinogenesis [68].

FHIT is a putative tumor suppressor gene that was isolated from the common fragile site FRA3B at 3p14.2 and found to have abnormal transcripts, with deleted exons in five of nine gastric cancer cases [69]. In other studies, genomic alterations and abnormal expression of FHIT were demonstrated in the majority of gastric carcinoma cases [70,71], suggesting that FHIT can play an important role in gastric carcinogenesis [71]. A recent study showed that abnormalities of FHIT, which are presumably associated with the unstable nature of FRA3B within the gene, are involved in the carcinogenesis of gastric cancer and that lack of mismatch repair possibly promotes its alteration in a subset of gastric cancer cases [72].

The candidate tumor suppressor gene $D C C$ is located on chromosome $18 \mathrm{q}$. $\mathrm{LOH}$ is frequently observed at the $D C C$ locus in well-differentiated but not poorly differentiated gastric cancer [73-76]. Yoshida et al. [74] observed decreased $D C C$ mRNA expression in 52 gastric cancers and reported that this decreased expression was closely associated with liver metastasis. A more recent study also reported that altered expression of DCC was detectable in gastric carcinomas, albeit more commonly at advanced stages of tumor progression [77].
Yet another gene, trefoil factor family 1 (TFF1), resides on chromosome 21q22, a region that has been noted to be deleted in gastric cancers in $\mathrm{LOH}$ studies [78]. TFF1 is synthesized and secreted by normal stomach mucosa and gastrointestinal cells of injured tissue. The link between mouse TFF1 inactivation and the fully penetrant antropyloric tumor phenotype prompted the classification of $T F F 1$ as a gastric tumor suppressor gene [79]. There is increasing evidence that TFF1 is a stabilizer of the mucous gel overlying the gastrointestinal mucosa, which provides a physical barrier against various noxious agents [78]. Altered expression, deletion, and/or mutations of the TFF1 gene have been frequently observed in human gastric carcinomas [79]. Also, loss of expression of TFF1 was observed in about $44 \%$ of gastric carcinoma cases $[78,80]$, while loss of the trefoil peptide was described in approximately $50 \%$ of gastric carcinoma cases [78,81]. Recently, researchers found evidence of a dual antiproliferative and antiapoptotic role of the TFF1 gene [79].

\section{Activation of oncogenes}

The group of activated oncogenes consists primarily of various growth factors and growth factor receptors. For example, in previous studies, the c-met protooncogene, which encodes a tyrosine kinase receptor for the hepatocyte growth factor, was overexpressed in $50 \%$ of both diffuse- and intestinal-type gastric cancers, indicating poor prognosis on multivariate analysis [50,82-85]. Tumors having overexpression of c-met have tended to display increased invasiveness and be poorly differentiated (including scirrhous tumors). Also, c-met is amplified and/or overexpressed but not mutated in several tumors, suggesting that overexpression of normal c-met, rather than structural alteration, is responsible for activation of the tyrosine kinase receptor $[86,87]$. Furthermore, rearrangement of the tpr and c-met genes has been reported in gastric cancer and identified in a small subset of gastric cancers [88].

The c-erB2 (HER-2/neu) gene, another protooncogene, is a transmembrane tyrosine kinase receptor. HER-2/neu protein overexpression or gene amplification is associated with approximately one-fourth of all gastrointestinal tract malignancies [89]. HER-2/neu overexpression also appears to be linked with advanced rather than early disease with limited invasion. The majority of studies of this protein have reported a significant prognostic value of HER-2/neu status, and overexpression of HER-2/neu has been implicated as a potential marker of poor prognosis in gastric cancers [87,90-92]. Other studies, however, have not found any prognostic value of HER-2/neu expression in these cancers [93]. 
Other oncogenes, such as cyclin E, c-erbB3, K-sam, Ras, and $c-m y c$, have also been found to be amplified and overexpressed in gastric carcinomas [94-96]. In particular, K-sam, which belongs to the fibroblast growth factor receptor family, is frequently overexpressed in diffuse-type gastric cancers, due to amplification of it $[45,97]$. Additionally, more enhanced expression of the Ras gene was found in intestinal-type gastric cancers than in diffuse-type cancers [98] and in advanced rather than in early gastric cancer $[99,100]$. Expression of $c-m y c$ has also been found to correlate with the disease stage, depth of invasion [101], and peritoneal dissemination [102].

\section{Telomerase reactivation}

Telomeres cover the ends of chromosomes and are important for maintenance of the integrity of the chromosomes [103]. Telomere length gradually shortens in normal cells in the absence of telomerase activity and the telomere acts as a mitotic clock controlling the number of times each cell divides, leading to replicating senescence [104]. While telomeres are shortened during cell division, this shortening is prevented in stem cells and transformed cells by the reactivation of telomerases, which adds a TTAGGG tandem to the $3^{\prime}$ end of the chromosomes [105]; thus, the cells do not undergo physiological senescence and acquire transforming capabilities. In addition, the reduction of telomere length may bring about genetic instability and telomerase reactivation. For example, a shorter than normal telomere length was observed in intestinal metaplasia [106], suggesting that this shortening plays a role in early carcinogenesis. In addition, telomerase is expressed during the early stages of gastric carcinogenesis [104]. Reactivation of telomerases has been reported in several malignancies, including gastric cancers, as well as in intestinal metaplasia $[107,108]$.

\section{Molecular determinants of gastric cancer invasion and metastasis}

Currently, gastric cancer is one of the best characterized neoplasms at the genetic level [6-9]. In contrast, the molecular mechanisms linked to the aggressive nature of this disease remain poorly understood. It has been suggested that its aggressive nature is related to the activation of various oncogenes and the inactivation of various tumor suppressor genes, as well as abnormalities in growth factors and their receptors, which affect the downstream signal transduction pathways involved in the control of cell growth and differentiation [9-12]. These perturbations confer a tremendous survival and growth advantage to gastric cancer cells, as manifested often by the development of invasive and metastatic phenotypes that are resistant to all conventional therapies [109]. Growth and metastasis of human gastric carcinoma is a highly selective process involving multiple tumor-host interactions [46,109]. A stressful tumor microenvironment, such as alteration of growthfactor production, oxidative stress, hypoxia, and acidosis, is the cause as well as the consequence of tumor progression [109].

\section{Alterations of growth factors and cytokines}

Chaotic production of various growth factors and cytokines is an important component of the tumor microenvironment. Numerous studies have established that human gastric cancer overexpresses many growth factors and their receptors, including the epidermal growth factor (EGF) family [49,50,97,110-112], vascular endothelial growth factor (VEGF) [50,113-115], fibroblast growth factor (FGF) [116,117], and insulin-like growth factor (IGF) [118-120], and numerous cytokines, such as TGF $[49,92,121,122]$, IL-1 [123,124], and IL-8 [125-127]. The abundance of growth-promoting factors and the disturbance of growth-inhibitory factors lead to evasion of programmed cell death and self-sufficiency in growth signals, and to elevated angiogenesis, tumor growth, and metastasis [46,109].

Some mechanisms have already been identified for the aberrant expression of the above growth factors. For example, increasing evidence suggests that VEGF expression is predominantly regulated by hypoxia, which is a common feature of most solid tumors, including gastric cancer. We have recently demonstrated that VEGF expression can be significantly upregulated by low extracellular $\mathrm{pH}$, or acidosis [128], which occur frequently within the expanding tumor mass and particularly in regions surrounding necrotic areas within tumors [129]. Similarly, we have also found that acidosis activates the $I L-8$ gene (data not shown). Both VEGF and IL-8 are key angiogenic molecules in gastric cancer. Detailed molecular biology studies have indicated that upregulation of these genes by acidosis may occur through the transactivation and cooperation of the transcription factors, nuclear factor (NF)- $\mathrm{\kappa B}$ and activating protein (AP-1) [130].

However, in many types of tumors, an elevated level of VEGF production can often be detected in tumor cells located in the extreme periphery of the tumor, where there is no apparent hypoxia and acidosis. These observations are consistent with numerous recent findings indicating that such exogenous factors as hormones, cytokines, and growth factors modulate VEGF expression and then angiogenesis [131]. Also, many tumor cells can constitutively express VEGF in vitro without any apparent external stimuli [132], which is 
consistent with the recent findings indicating that loss or inactivation of tumor suppressor genes and activation of oncogenes are associated with VEGF overexpression [133]. In fact, VEGF promoter analyses have revealed several potential transcription factor binding sites, such as HIF-1, AP-1, AP-2, Egr-1, Sp1, Stat3, and many others [134], suggesting that multiple signal transduction pathways may be involved in VEGF transcription regulation. For example, differential constitutive Sp1 activation is essential for different VEGF expression [132]. Our recent studies have also found that constitutively activated Stat 3 directly contributes to the constitutive VEGF expression in human cancer cells [135]. Without apparent external stimuli, human cancer cells also constitutively expresses IL-8 through constitutively activated NF- $\kappa$ B and AP-1 $[130,136]$.

Therefore, aberrant expression of multiple metastasis-related proteins such as IL-8 and VEGF may result from alterations of the activities of several transcription factors. Here, we propose two potential pathways. One mechanism relates to the genetic mutations of oncogenes and/or suppressor genes, such as Ras and $p 53$, resulting in constitutive activation of the transcription factors. This may be especially true in the early stage of gastric cancer growth. In the late stage of gastric cancer development, however, notable "stress factors", such as hypoxia and acidosis that are often seen in the tumor microenvironment, further upregulate these metastasis-related proteins through overactivating the transcription factors. Therefore, at advanced stages, uncontrolled tumor growth and the consequent development of a stress environment may enhance tumor angiogenesis, growth, and metastasis. Understanding the expression and regulation of these molecules may shed more light on the pathophysiology of gastric cancer, as well as suggest new targets for preventive and therapeutic approaches to metastatic gastric cancer.

\section{Apoptosis and cell-cycle regulators}

Apoptosis, or programmed cell death, plays a fundamental role in multicellular organisms [137]. Genes that regulate apoptosis, such as $F A S$, tumor necrosis factor $(T N F)$, and $b c l-2$, contribute to the development of cancer. LOH at the $b c l-2$ locus, an apoptosis inhibitor localized at the inner mitochondrial membrane, is associated with intestinal-type gastric tumors $[29,45,138,139]$, while expression of an apoptosis receptor antigen recognized by SC- 1 antibody is preferentially seen in diffusetype tumors [139]. Additionally, studies have found a higher level of apoptosis in gastric tumors in early development than in those showing progression to adenocarcinoma [140-143]. However, Koshida et al. [143] reported lower levels of apoptosis in early-stage gastric cancers when compared with advanced-stage cancers.
Recently, a study showed a significantly higher level of apoptosis and cell proliferation in differentiated than in undifferentiated early-stage gastric cancers, indicating that apoptosis and proliferation are in balance to contain development in the early stages of these cancers [144].

Abnormalities in cell-cycle regulators are also involved in the development and progression of gastric cancers through unbridled cell proliferation [67]. Specifically, genetic alterations and abnormal expression of various cyclins and cyclin-dependent kinases (CDKs), as well as CDK inhibitors, play a role in gastric cancer pathogenesis. Amplification of cyclin $\mathrm{E}$ has been found in $10 \%$ of diffuse-type and $20 \%$ of intestinal-type gastric cancers, particularly at advanced stages of the latter [145]. In addition, overexpression of cyclin E tends to be correlated with advanced tumor stage, invasiveness, and histological grade $[67,145]$. Furthermore, cyclin D1 overexpression has been found in approximately $50 \%$ of gastric cancers, but more commonly in the intestinal type than in the diffuse type [146]. On the other hand, decreased expression of the CDK inhibitor P27 kip1 is frequently associated with advanced gastric carcinomas [147] and is significantly correlated with the depth of tumor invasion and presence of lymph node metastasis [67].

\section{Alterations of adhesion molecules}

In addition to the activation of oncogenes and inactivation of tumor suppressor genes, alteration of adhesion molecules seems to be critical for the development of gastric cancer. For instance, E-cadherin is a binding partner of $\beta$-catenin and plays a crucial role in establishing intercellular adhesion and the structural integrity of epithelial tissues [148,149]. E-cadherin belongs to the cadherin superfamily and is involved in maintenance of the epithelial phenotype. Reduction or loss of Ecadherin expression has been found often in gastric cancers, probably because of hypermethylation of the E-cadherin promoter [7,150]. A more recent study showed that abnormal E-cadherin expression is a possible marker of submucosal invasion in early differentiated-type gastric cancer and that a lack of $\beta$-catenin staining can be used as a predictor of lymph node metastasis in both the intestinal and diffuse types of gastric cancer [151]. In addition, dysfunction of the E-cadherin-catenin complex has been shown to occur at an early stage of gastric carcinogenesis [148]. Somatic mutations in E-cadherin have been detected in $50 \%$ of diffuse-type gastric cancer cases; in comparison, loss of the remaining allele, resulting in complete inactivation of the protein, was seen in more than $75 \%$ of the cases with mutation $[152,153]$. Somatic E-cadherin mutations are typically in-frame deletions, removing partial or 
complete sequences from the mRNA, or point mutations, resulting in single amino-acid changes [45]. Cell culture experiments have demonstrated that E-cadherin mutations result in markedly reduced cell adhesion, altered morphology, and enhanced cellular motility [154]. Thus, these mutations actively contribute to the morphology of the tumors. E-cadherin mutations are absent from intestinal-type tumors, however. Because of its tumor specificity and biological relevance for malignancy, mutant E-cadherin is an excellent marker for diagnosis and a very attractive target for novel therapeutic interventions [45,48,97,115,155-158].

\section{Nitric oxide synthase (NOS)}

Nitric oxide (NO) is a potent biological molecule that mediates a diverse array of activities, including vasodilatation, neurotransmission, iron metabolism, and immune defense $[159,160]$. Recent studies have suggested that tumor-associated $\mathrm{NO}$, which is, presumably, produced by tumor and/or host cells (e.g., macrophages) that infiltrate and surround tumors, has pleiotropic effects on carcinogenesis, tumor growth, and metastasis [161-166]. The outcome apparently depends on the genetic and epigenetic makeup of tumor cells as well as the source and level of NO production, which itself is dictated by the isoforms of NO synthases (NOSs), i.e., NOS I, NOS II, and NOS III [166]. It is generally believed that a low level of NO production, mostly from elevated expression of NOS I and NOS III (constitutive NOS), most likely benefits tumor growth through increasing tumor blood perfusion and angiogenesis $[161,166]$. However, expression of NOS II (inducible NOS) can have the opposite effects, mainly because of the high NO production and long-lasting half-life of the NOS II enzyme.

NOS II expression and NO production within tumor cells can directly or indirectly influence the fate of the cells themselves [161-166]. Expression of the NOS II gene inversely correlates with the metastatic ability of human colon cancer [167] and K-1735 murine melanoma cells [168]. Also, overproduction of endogenous NO is autocytotoxic through the induction of apoptosis [166] and suppresses tumor growth and metastasis $[166,169]$. Expression of NOS II in tumor stromal cells, e.g., infiltration macrophages and vascular endothelial cells, has also been implicated in tumor progression and may be the major source of tumor-associated NO $[159,160,166,170]$. Activated macrophages and endothelial cells may produce $\mathrm{NO}$ at cytotoxic levels in vitro $[159,166,170]$ and prevent tumor growth and metastasis, presumably by killing tumor cells passing through vascular lumens [166].

Conversely, the role of NOS II in tumor growth is complex and not fully understood. There is a body of evidence indicating that NOS II may promote tumor growth and metastasis. Specifically, tumor-associated NOS II activity correlates with more advanced human tumors of the breast [171] and central nervous system [172]. In fact, NOS II expression directly correlates with the metastatic potential of UV-2237 murine fibrosarcoma cells [159]. In addition, macrophage-derived NO may promote tumor growth and metastasis through multiple mechanisms, such as regulation of immune response, cell survival, blood flow, and vessel formation $[159,160,173]$. Consistently, enforced low levels of NOS II expression have been shown to positively influence tumor progression by protecting tumor cells from apoptosis [174] and altering tumor blood supply through changing vascular tone and/or formation [161,175]. NO also stimulates vascular endothelial cell proliferation and migration directly or indirectly by inducing the expression of VEGF [176,177].

However, the expression and potential role of NOS II and NOS III in the pathogenesis of human gastric cancer are mostly unknown. Recent studies showed elevated NOS II and NOS III expression in human gastric cancer specimens, which has been interpreted as inhibiting or promoting tumor progression [178-184]. Clearly, the definitive roles of NO in gastric cancer development and progression remain to be determined.

\section{Cyclooxygenase (COX)-2}

COX-2, one of the two key enzymes in the conversion of arachidonic acid to prostanoids, is the target of inhibition by nonsteroidal anti-inflammatory drugs. Increased expression of COX-2 has been associated with inflammatory processes and carcinogenesis $[185,186]$ and has been detected in several common human malignancies, predominantly of the gastrointestinal tract, including colorectal, esophageal, and gastric carcinomas [187]. COX-2 overexpression is common in intestinal-type gastric carcinoma and dysplastic precursor lesions, suggesting a relatively early role for $\mathrm{COX}-2$ expression in gastric carcinogenesis [188,189]. Additionally, COX-2 overexpression is inversely associated with MSI in gastric cancer [190]. COX-2 overexpression in epithelial cells inhibits apoptosis and increases the invasiveness of malignant cells, favoring tumorigenesis and metastasis [191]. Transcriptional repression of COX-2 has been shown to be caused by hypermethylation of the COX$2 \mathrm{CpG}$ island in gastric carcinoma cell lines [192]. In addition, promoter methylation regulates $H$. pyloristimulated COX-2 expression in gastric epithelial cells [193]. Loss of COX-2 methylation may facilitate COX-2 expression and promote gastric carcinogenesis associated with $H$. pylori infection [194]. In one study, after successful eradication of $H$. pylori, expression of COX-2 was reduced but not eliminated in the epithelium [195]. 
Table 1. Major molecular markers of intestinal-type and diffuse-type human gastric cancer, and potential clinical applications

\begin{tabular}{|c|c|c|c|c|c|}
\hline \multirow[b]{2}{*}{ Molecules } & \multirow[b]{2}{*}{ Alteration } & \multicolumn{2}{|c|}{ Percentage } & \multirow[b]{2}{*}{ Application } & \multirow[b]{2}{*}{ References } \\
\hline & & Diffuse & Intestinal & & \\
\hline \multicolumn{6}{|c|}{ Tumor suppressors } \\
\hline p53 & Mutation, LOH & \multicolumn{2}{|c|}{$20-80$} & $\mathrm{DA}, \mathrm{TT}$ & 41,42 \\
\hline APC & Mutation, LOH & 30 & $40-60$ & $\mathrm{DA}$ & $48-50$ \\
\hline DCC & $\mathrm{LOH}$ & 0 & 50 & $\mathrm{DA}$ & 75,76 \\
\hline CDH1 & Mutation & 50 & 0 & $\mathrm{RA}, \mathrm{DA}, \mathrm{TT}$ & $49,155-157$ \\
\hline$\beta$-Catenin & Mutation & 0 & 30 & DA & $45,97,115,158$ \\
\hline \multicolumn{6}{|l|}{ Oncogenes } \\
\hline $\mathrm{K}$-ras & Mutation & 0 & 10 & DA, TT & 50,112 \\
\hline$b c l-2$ & $\mathrm{LOH}$ & 0 & 40 & $\mathrm{DA}$ & $29,45,139$ \\
\hline$c-m e t$ & Amplification & 40 & 20 & $\mathrm{PF}$ & $29,48,85$ \\
\hline K-sam & Amplification & 30 & 0 & $\mathrm{PF}$ & 45,97 \\
\hline$c$-cerB2 & Amplification & 0 & 20 & $\mathrm{PF}, \mathrm{TT}$ & 83,92 \\
\hline MSI & & \multicolumn{2}{|c|}{$10-40$} & $\mathrm{DA}, \mathrm{PF}$ & $9,10,36$ \\
\hline \multicolumn{6}{|c|}{ Growth factor/receptors } \\
\hline EGFR & Overexpression & 25 & 50 & PF, TT & 50,112 \\
\hline $\mathrm{EGF}$ & Overexpression & 50 & 40 & PF, TT & 48,97 \\
\hline TGF- $\alpha$ & Overexpression & 55 & 60 & $\mathrm{PF}, \mathrm{TT}$ & 50,92 \\
\hline VEGF & Overexpression & 10 & 45 & $\mathrm{PF}, \mathrm{TT}$ & 48,115 \\
\hline \multicolumn{6}{|c|}{ Transcription factors } \\
\hline CDX1 & Overexpression & 50 & 40 & $\mathrm{PF}, \mathrm{TT}$ & 200 \\
\hline $\mathrm{CDX} 2$ & Overexpression & 60 & 50 & $\mathrm{PF}, \mathrm{TT}$ & 200 \\
\hline Ets1 & Overexpression & \multirow{2}{*}{\multicolumn{2}{|c|}{$\begin{array}{l}65 \\
25\end{array}$}} & $\mathrm{PF}, \mathrm{TT}$ & 201,202 \\
\hline$N F-\kappa B$ & Overexpression & & & $\mathrm{PF}, \mathrm{TT}$ & 203 \\
\hline $\mathrm{Sp}-1$ & Overexpression & 35 & 20 & $\mathrm{PF}, \mathrm{TT}$ & 115 \\
\hline
\end{tabular}

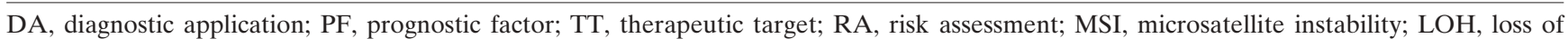
heterozygosity

Other candidate genes that have been identified to play an important role in cell-cell adhesion and metastasis include CD44 [196], nm23 [197], matrix metalloproteinase-2 [10], and plasminogen activator type 1 (PAI-1) [198]. Moreover, the expression and regulation of mucin and glycoconjugate also play important roles in the pathological processes of $H$. pylori infection and gastric carcinogenesis [199]. Interestingly, several recent studies have shown that the aberrant expression of transcription factors contributes to gastric cancer development and progression. These factors included CDX1 [200], CDX2 [200], Ets1 [201,202], NF-кB [203], and Sp1 [115]. For example, Sp1 overexpression has been shown to predict poor clinical outcome of gastric cancer [115]. Major molecular markers for the diffuse- and intestinal-type of gastric cancer and their potential applications are summarized in Table 1.

\section{Molecular changes associated with $\boldsymbol{H}$. pylori infection}

The etiological features of $H$. pylori in gastric carcinoma are based mainly on epidemiological studies [1]. Although it is fairly well accepted that $H$. pylori infection plays a role in causing gastric cancer, the exact mechanisms involved in its pathogenesis are unclear. $H$. pylori infection leads to different clinical and pathological outcomes in humans, including chronic gastritis, peptic ulcer disease, and gastric carcinoma [1]. H. pylori also was recently shown to be associated with molecular changes that developed in the gastric carcinogenesis process [204].

Accumulating evidence suggests that $H$. pylori induces cell proliferation and apoptosis during early chronic inflammation of the gastric mucosa, whereas in malignant transformation of the gastric mucosa, apoptosis is inhibited, and adhesion of gastric epithelial cells is impaired [2]. Studies have shown significantly increased apoptotic cells in $H$. pylori-infected gastric tissues throughout the depth of gastric glands compared with that in uninfected gastric tissue samples and after H. pylori eradication $[205,206]$. It has also been reported that incubation of cultured gastric cancer cell lines with $H$. pylori strains leads to increased cell proliferation [207]. Also, downregulation of the E-cadherin protein has been associated with $H$. pylori infection in patients with normal gastric mucosa, gastritis, a gastric ulcer, or a duodenal ulcer [208]. Furthermore, a study of individuals with a family history of gastric cancer revealed an association between reduced $\alpha$-catenin 
expression and H. pylori infection of the gastric mucosa [209]. Recently, Shibata et al. [210] reported that CagA(+) H. pylori infection, when compared with CagA (-) infection or the absence of $H$. pylori infection, was associated with a higher prevalence of $p 53$ mutations in gastric adenocarcinoma cases. Similarly, Kubicka et al. [211] found more p53 mutations in patients with serology positive for H. pylori $(43 \%)$ than in patients with $H$. pylori-negative serology (14\%) [210,211]. Wang et al. [212] reported that H. pylori infection may increase the expression of ras p21 proteins and induce $p 53$ suppressor gene mutation early in the gastric carcinogenesis process. However, the expression of various oncogenes (e.g., K-ras, c-erbB2) and MSI is independent of $H$. pylori infection [212-215]. Interestingly, Churin and colleagues [216] recently found that H. pylori CagA protein targets the c-Met receptor and enhances the motogenic response, suggesting that $H$. pylori might be involved in aggressive gastric cancer.

Mucosal growth-promoting factors such as gastrin, hepatocyte growth factor (HGF), and TGF- $\alpha$ may play an important role in the transformation of normal $H$. pylori-infected gastric mucosal cells into malignant cells [216,217]. Specifically, increased production of gastrin and overexpression of HGF and TGF- $\alpha$ contribute to gastric carcinogenesis through activation of the NF- $\mathrm{KB}-$ dependent cytokines IL-8 and TGF- $\alpha$ [216,217]. Recent molecular studies have also revealed that $H$. pylori injects bacterial proteins into the cytosol of gastric cells via the type IV injection system and regulates intracellular signal transduction in host cells [218], which is a novel means of survival. Further molecular evidence is needed to elucidate $H$. pylori infection as an etiological factor for gastric carcinogenesis.

\section{Clinical applications}

\section{Molecular diagnosis}

Based on the molecular pathology findings described above, it is possible to improve the quality of histopathological diagnosis by analyzing genetic and epigenetic alterations. Understanding the structure and function of gastric cancer-associated genes is fundamental for establishing methods of gastric cancer diagnosis and quantification of an individual's risk of the disease. More and more molecular diagnostic markers are being identified to aid in the diagnosis of gastric cancer, e.g., p53, APC, and CD44 have been used as markers for differential diagnosis; epidermal growth factor receptor (EGFR), c-met, and c-erbB2 have been used as markers for the degree of malignancy; and MSI has been used as a marker for the screening of genetic instability [67].

MSI causes accumulation of genetic alterations and has been recognized as one of the earliest changes in gastric carcinogenesis. Identifying patients with genetic instabilities may help identify those at risk for carcinomas. MSI is detected in both gastric adenoma and intestinal metaplasia, which are precancerous lesions associated with well-differentiated gastric cancers [219]. A recent report showed that MSI and hypermethylation-associated inactivation of hMLH1 were more prevalent in early gastric cancers than in gastric adenomas [220]. Techniques of detecting MSI are promising for the early diagnosis of tumors before they become microscopically obvious.

Researchers have found that inactivation of the $p 53$ and $A P C$ genes in early gastric cancer can be used for early detection, whereas the amplification and overexpression of c-met, K-sam, c-erbB2, and cyclin E, and the overexpression of growth factors are indicators of high-grade tumors [67]. Recently, an increasing number of technologies, such as laser microdissection, have become available for gastric cancer diagnosis. In addition, the DNA microarray technique is a powerful tool for identifying novel genes that participate in the development and progression of gastric cancer [67].

The ability to identify individuals who have an inherited risk of gastric cancer would allow more intensive clinical surveillance, early detection, and improved diagnosis [221]. Recently, direct proof of a distinct gastric cancer syndrome resulted from the identification of germline E-cadherin mutations cosegregating in three large Maori families in New Zealand [221]. Thus far, many inactivating germline mutations in the E-cadherin gene have been identified in families in whom diffusetype gastric cancer is frequently diagnosed [222]. Many other genetic and epigenetic alterations in the Ecadherin gene are also evident [223-227]. These findings demonstrate that E-cadherin gene alterations are a common cause of gastric cancer.

\section{Prognosis}

The use of molecular markers as tumor and prognostic markers seems to be promising. Evaluating molecular markers in relation to clinical outcome should provide information about the use of these genetic alterations as prognostic markers, which could influence the design of a therapeutic concept for individual patients $[10,45]$. Although prognostic studies have been inconsistent, one recent study showed that $p 53$ mutations were significantly correlated with poor survival after potentially curative resection of gastric cancer [210]. Also, SanzOrtega et al. [228] reported that p53 protein expression showed a statistically significant association with overall survival and was correlated with cardia location, nodal involvement, and tumor stage in patients with gastric cancer, while c-erbB2 and c-myc were significantly enhanced in well-differentiated tumors with a worse prog- 
nosis [229]. Furthermore, overexpression of c-erbB2 has been found in intestinal tumors and may serve as a prognostic marker for tumor invasion and lymph node metastasis; therefore, it may be linked with poor prognosis [228]. Overexpression of some growth factors, such as EGF, EGF receptor (EGFR), TGF- $\alpha$, and VEGF, correlates with tumor malignancy and lymph node metastasis and indicates a worse prognosis for gastric cancer patients [45]. In addition, Akama et al. [145] have reported that cyclin E overexpression correlates with staging, invasiveness, and proliferation of gastric cancer and may be a marker for aggressiveness. Reduced expression of the cell-cycle inhibitor p16 ${ }^{\mathrm{MTSI}}$, which correlates with the depth of invasion and potential for metastasis, was also reported, although somatic mutations of it are very rare [45]. Additionally, studies of MSI have shown a statistically significant association of it with a lack of lymphatic infiltration within the tumor and a tendency for it to be associated with longer survival [230], although more extensive studies are needed to clarify the value of MSI as an independent prognostic factor. Other reported independent prognostic factors include tumor-associated proteases and urokinase-type plasminogen activator (uPA) and its inhibitor (PAI-1). In particular, elevated UPA and PAI-1 levels were shown to be associated with poor prognosis and shorter survival [231,232].

\section{Therapeutic applications}

With the better understanding of the molecular mechanisms of gastric cancer, new therapeutic targets are now available. Agents that specifically block the catalytic activity of protein tyrosine kinases provide an alternative strategy for the development of novel antitumor agents [10]. These include naturally occurring compounds isolated from fungal extracts, and the synthetic tyrosine phosphorylation inhibitors, known as tyrphostins [233]. A therapeutic approach for gastric cancer, using monoclonal antibodies, e.g., SC-1 (isolated from a patient with signet-ring cell carcinoma) and CH401 (an anti-erbB2 mouse-human chimeric monoclonal antibody), also has been reported [234,235]. Specifically, SC-1 was shown to react with a 50-kDa surface molecule expressed by gastric carcinoma cells; it induces apoptosis and inhibits proliferation of gastric carcinoma cells in vitro and can significantly reduce gastric cancer growth in vivo [236]. Also, CH401 was reported to be able to kill gastric cancer cells overexpressing the erbB2 protein in vitro by inducing apoptosis in the cells [237]. In addition, E-cadherin mutation-specific monoclonal antibodies were reported to react with $13 \%$ of Ecadherin-positive diffuse-type gastric cancers [238]. The concept of the induction of tumor-specific apoptosis by monoclonal antibodies may produce a novel type of adjuvant cancer therapy [45]. The antibodies may also be used in a gene therapy approach for the introduction of a costimulator to activate the patient's immune system or to generate specific antibodies that recruit immune cells to tumor cells [239].

The recent development of high-throughput technologies for analyzing thousands of single-nucleotide polymorphisms (SNPs) in drug-handling genes may revolutionize the field of pharmacogenomics [240]. Particularly, polymorphisms in metabolizing genes may have the potential to predict the effectiveness of chemotherapy. In this way, the molecular profile of a tumor may suggest a certain drug combination, and the patient's SNP "makeup” may dictate the schedule [241].

\section{Future directions}

Gastric cancer is an interesting model for studying carcinogenesis and tumorigenesis because it represents a heterogeneous condition. Although much has been learned about the molecular basis of gastric cancer, the detailed mechanisms of gastric cancer development remain unclear. Various genetic and molecular alterations that are present in gastric cancer underlie the malignant transformation of the gastric mucosa during the multistep process of gastric cancer pathogenesis. However, the rapid development of molecular biology technologies such as laser-based microdissection techniques [241,242] and cDNA microarrays [243] makes further molecular analysis of gastric cancer possible. Using cDNA microarray analysis, the expression of hundreds of potential molecular markers can be evaluated in a short period of time [244], in contrast with the current capability to assay only a single or few molecules. For example, Boussioutas and colleagues [245] have recently shown some exciting results on the expression signatures that are characteristic of premalignant gastric mucosa or gastric cancers. The identification of apparent mitochondrial stress in chronic gastritis has important implications for the major molecular effects of $H$. pylori infection on parietal and epithelial cells, and possibly for the initiation of the premalignant process of gastric cancer. Intestinal-type gastric cancer is characterized by a proliferative signature, in contrast to diffuse-type gastric cancer, and this signature suggests that patients with intestinal-type gastric cancer may particularly benefit from antiproliferative chemotherapeutic agents [245]. In addition, because of the multiple molecular alterations, as well as complications in the histopathology of gastric cancer, the significance of these molecular changes in gastric pathogenesis remains to be further elucidated. Illustration and characterization of the critical molecular alterations in gastric cancer may hold great promise for screening, enhancing 
classification, diagnosis, prognosis, and most importantly, developing therapeutic targets in the near future.

Acknowledgments The gastric cancer research was supported in part by Research Scholar Grant CSM-106640 from the American Cancer Society and by Grant 1R01CA093829 and Cancer Center Support Core Grant CA 16672-23 from the National Cancer Institute, National Institutes of Health (to K. Xie). We thank Judy King for expert help in the preparation of this manuscript and Don Norwood for editorial comments.

\section{References}

1. Terry MB, Gaudet MM, Gammon MD. The epidemiology of gastric cancer. Semin Radiat Oncol 2002;12:111-27.

2. Ebert MP, Schandl L, Malfertheiner P. Helicobacter pylori infection and molecular changes in gastric carcinogenesis. J Gastroenterol 2002;37(Suppl 13):45-9.

3. Kapadia CR. Gastric atrophy, metaplasia, and dysplasia: a clinical perspective. J Clin Gastroenterol 2003;36(5 Suppl):S29-36.

4. Misdraji J, Lauwers GY. Gastric epithelial dysplasia. Semin Diagn Pathol 2002;19:20-30.

5. Clouston AD. Timely topic: premalignant lesions associated with adenocarcinoma of the upper gastrointestinal tract. Pathology 2001;33:271-7.

6. Ebert MP, Fei G, Kahmann S, Muller O, Yu J, Sung JJ, et al. Increased beta-catenin mRNA levels and mutational alterations of the APC and beta-catenin gene are present in intestinal-type gastric cancer. Carcinogenesis 2002;23:87-91.

7. Tamura G, Yin J, Wang S, Fleisher AS, Zou T, Abraham JM, et al. E-Cadherin gene promoter hypermethylation in primary human gastric carcinomas. J Natl Cancer Inst 2000;92:569-73.

8. Fiocca R, Luinetti O, Villani L, Mastracci L, Quilici P, Grillo F, et al. Molecular mechanisms involved in the pathogenesis of gastric carcinoma: interactions between genetic alterations, cellular phenotype and cancer histotype. Hepatogastroenterology 2001;48:1523-30.

9. El-Rifai W, Powell SM. Molecular biology of gastric cancer. Semin Radiat Oncol 2002;12:128-40.

10. Chan AO, Luk JM, Hui WM, Lam SK. Molecular biology of gastric carcinoma: from laboratory to bedside. J Gastroenterol Hepatol 1999;14:1150-60.

11. Danesh J. Helicobacter pylori infection and gastric cancer: systematic review of the epidemiological studies. Aliment Pharmacol Ther 1999;13:851-6.

12. Stadtlander CT, Waterbor JW. Molecular epidemiology, pathogenesis and prevention of gastric cancer. Carcinogenesis 1999;20:2195-208.

13. González CA, Sala N, Capellá G. Genetic susceptibility and gastric cancer risk. Int J Cancer 2002;100:249-60.

14. Huntsman DG, Carneiro F, Lewis FR, MacLeod PM, Hayashi A, Monaghan KG, et al. Early gastric cancer in young, asymptomatic carriers of germ-line E-cadherin mutations. N Engl J Med 2001;344:1904-9.

15. El-Omar EM, Carrington M, Chow WH, McColl KEL, Bream $\mathrm{JH}$, Young HA, et al. Interleukin-1 polymorphisms associated with increased risk of gastric cancer. Nature 2000;404:398-402.

16. Perera FP, Weistein IB. Molecular epidemiology: recent advances and future directions. Carcinogenesis 2000;21:517-24.

17. Ames BN. Cancer prevention and diet: help from single nucleotide polymorphisms. Proc Natl Acad Sci USA 1999;96:12216-8.

18. Garte S. Metabolic susceptibility genes as cancer risk factors: time for a reassessment? Cancer Epidemiol Biomarkers Prev 2001;10:1233-7.
19. Takezaki T, Gao CM, Wu JZ, Li ZY, Wang JD, Ding JH, et al. hOGG1 Ser(326)Cys polymorphism and modification by environmental factors of stomach cancer risk in Chinese. Int J Cancer 2002;99:624-7.

20. Shen H, Xu Y, Zheng Y, Qian Y, Yu R, Qin Y, et al. Polymorphisms of 5,10-methylenetetrahydrofolate reductase and risk of gastric cancer in a Chinese population: a case-control study. Int J Cancer 2001;95:332-6.

21. Shen H, Xu Y, Qian Y, Yu R, Qin Y, Zhou L, et al. Polymorphisms of the DNA repair gene XRCC1 and risk of gastric cancer in a Chinese population. Int J Cancer 2000;88:6016.

22. Machado JC, Pharoah P, Sousa S, Carvalho R, Oliveira C, Figueiredo $\mathrm{C}$, et al. Interleukin $1 \mathrm{~B}$ and interleukin $1 \mathrm{RN}$ polymorphisms are associated with increased risk of gastric carcinoma. Gastroenterology 2001;121:823-9.

23. Boissy RJ, Watson MA, Umbach DM, Deakin M, Elder J, Strange C, et al. A pilot study investigating the role of NAT1 and NAT2 polymorphisms in gastric adenocarcinoma. Int J Cancer 2000;87:507-11.

24. Katoh T, Boissy RJ, Nagata N, Kitagawa K, Kuroda Y, Itoh H, et al. Inherited polymorphism in the $\mathrm{N}$-acetyltransferase 1 (NAT1) and 2 (NAT2) genes and susceptibility to gastric and colorectal adenocarcinoma. Int J Cancer 2000;85:46-9.

25. El-Omar EM, Chow WH, Rabkin CS. Gastric cancer and $H$. pylori: host genetics open the way. Gastroenterology 2001;121: 1002-5.

26. Correa P. Human gastric carcinogenesis. A multistep and multifactorial process - first American Cancer Society Award Lecture on cancer epidemiology and prevention. Cancer Res 1992; 52:6735-40.

27. Meining A, Morgner A, Miehlke S, Bayerdorffer E, Stolte M. Atrophy-metaplasia-dysplasia-carcinoma sequence in the stomach: a reality or merely an hypothesis? Best Pract Res Clin Gastroenterol 2001;15:983-98.

28. Werner M, Becker KF, Keller G, Höfler H. Gastric adenocarcinoma: pathomorphology and molecular pathology. J Cancer Res Clin Oncol 2001;127:207-16.

29. Werner M, Becker KF, Keller G, et al. Gastric adenocarcinoma: pathomorphology and molecular pathology. J Cancer Res Clin Oncol 2001;127:207-16.

30. Tahara E, Semba S, Tahara H. Molecular biological observations in gastric cancer. Semin Oncol 1996;23:307-15.

31. Tamura G. Genetic and epigenetic alterations of tumor suppressor and tumor-related genes in gastric cancer. Histol Histopathol 2002;17:323-9.

32. Miyoshi E, Haruma K, Hiyama T, Tanaka S, Yoshihara M, Shimamoto F, et al. Microsatellite instability is a genetic marker for the development of multiple gastric cancers. Int $\mathbf{J}$ Cancer 2001;95:350-3.

33. Hayden JD, Martin IG, Cawkwell L, Quirke P. The role of microsatellite instability in gastric carcinoma. Gut 1998;42:3003.

34. Leung SY, Yuen ST, Chung LP, Chu KM, Chan AS, Ho JC. hMLH1 promoter methylation and lack of hMLH1 expression in sporadic gastric carcinomas with high-frequency microsatellite instability. Cancer Res 1999;59:159-64.

35. Iacopetta BJ, Soong R, House AK, Hamelin R. Gastric carcinomas with microsatellite instability: clinical features and mutations to the TGF-beta type II receptor, IGFII receptor, and BAX genes. J Pathol 1999;187:428-32.

36. Halling KC, Harper J, Moskaluk CA, Thibodeau SN, Petroni GR, Yustein AS, et al. Origin of microsatellite instability in gastric cancer. Am J Pathol 1999;155:205-11.

37. Ranzani GN, Luinetti O, Padovan LS, Calistri D, Renault B, Burrel M, et al. p53 gene mutations and protein nuclear accumulation are early events in intestinal type gastric cancer but late events in diffuse type. Cancer Epidemiol Biomarkers Prev $1995 ; 4: 223-31$. 
38. Brito MJ, Williams GT, Thompson H, Filipe MI. Expression of p53 in early (T1) gastric carcinoma and precancerous adjacent mucosa. Gut 1994;35:1697-700.

39. Wang JY, Lin SR, Hsieh JS, Hsu CH, Huang YS, Huang TJ. Mutations of p53 gene in gastric carcinoma in Taiwan. Anticancer Res 2001;21:513-20.

40. Hollstein M, Shomer B, Greenblatt M, Soussi T, Hovig E, Montesano R, et al. Somatic point mutations in the p53 gene of human tumors and cell lines: updated compilation. Nucleic Acids Res 1996;24:141-6.

41. Fenoglio-Preiser CM, Wang J, Stemmermann GN, Noffsinger A. TP53 and gastric carcinoma: a review. Hum Mutat 2003;21:25870.

42. Imazeki $\mathrm{F}$, Omata $\mathrm{M}$, Nose $\mathrm{H}$, Ohto $\mathrm{M}$, Isono $\mathrm{K}$. p53 gene mutations in gastric and esophageal cancers. Gastroenterology 1992;103:892-6.

43. Kim JH, Takahashi T, Chiba I, Park JG, Birrer MJ, Roh JK, et al. Occurrence of p53 gene abnormalities in gastric carcinoma tumors and cell lines. Natl Cancer Inst 1991;83:939-43.

44. Yamada Y, Yoshida T, Hayashi K, Sekiya T, Yokota J, Hirohashi S, et al. p53 gene mutations in gastric cancer metastases and in gastric cancer cell lines derived from metastases. Cancer Res 1991:51:5800-5.

45. Becker KF, Keller G, Hoefler H. The use of molecular biology in diagnosis and prognosis of gastric cancer. Surg Oncol 2000;9:511.

46. Tahara E. Genetic alterations in human gastrointestinal cancers. Cancer 1995;75:1410-7.

47. Horii A, Nakatsuru S, Miyoshi Y, Ichii S, Nagase H, Kato Y, et al. The APC gene, responsible for familial adenomatous polyposis, is mutated in human gastric cancer. Cancer Res 1992;52: 3231-3.

48. Hanna NN, Mentzer RM Jr. Molecular genetics and management strategies in hereditary cancer syndromes. J Ky Med Assoc 2003;101:100-7.

49. Hofler H, Becker KF. Molecular mechanisms of carcinogenesis in gastric cancer. Recent Results Cancer Res 2003;162:65-72.

50. Yokozaki H, Yasui W, Tahara E. Genetic and epigenetic changes in stomach cancer. Int Rev Cytol 2001;204:49-95.

51. Nakatsuru S, Yanagisawa A, Ichii S, Tahara E, Kato Y, Nakamura Y, et al. Somatic mutation of the APC gene in gastric cancer: frequent mutations in very well differentiated adenocarcinoma and signet-ring cell carcinoma. Hum Mol Genet 1992;1:559-63.

52. Lee JH, Abraham SC, Kim HS, Nam JH, Choi C, Lee MC, et al. Inverse relationship between APC gene mutation in gastric adenomas and development of adenocarcinoma. Am J Pathol 2002;161:611-8.

53. Hsieh LL, Huang YC. Loss of heterozygosity of APC/MCC gene in differentiated and undifferentiated gastric carcinoma in Taiwan. Cancer Lett 1995;96:169-74.

54. Munemitsu S, Albert I, Souza B, Rubinfeld B, Polakis P. Regulation of intracellular $\beta$-catenin levels by the adenomatous polyposis coli (APC) tumor-suppressor protein. Proc Natl Acad Sci USA 1995;92:3046-50.

55. Peifer M. Signal transduction. Neither straight nor narrow. Nature 1999;400:213-5.

56. Park WS, Oh RR, Park JY, Lee SH, Shin MS, Kim YS, et al. Frequent somatic mutations of the beta-catenin gene in intestinal-type gastric cancer. Cancer Res 1999;59:4257-60.

57. Candidus S, Bischoff P, Becker KF, Höfler H. No evidence for mutations in alpha and beta-catenin genes in human gastric and breast carcinomas. Cancer Res 1996;56:49-52.

58. Eads CA, Lord RV, Kurumboor SK, Wickramasinghe K, Skinner ML, Long TI, et al. Fields of aberrant $\mathrm{CpG}$ island hypermethylation in Barrett's esophagus and associated adenocarcinoma. Cancer Res 2000;60:5021-6.

59. Igaki $H$, Sasaki $H$, Tachimori $Y$, Kato $H$, Watanabe $H$, Kimura $\mathrm{T}$, et al. Mutation frequency of the $\mathrm{p} 16 / \mathrm{CDKN} 2$ gene in primary cancers in the upper digestive tract. Cancer Res 1995;55:34213.

60. Klump B, Hsieh CJ, Holzmann K, Gregor M, Porschen R. Hypermethylation of the CDKN2/p16 promoter during neoplastic progression in Barrett's esophagus. Gastroenterology 1998; 115:1381-6.

61. Shim YH, Kang GH, Ro JY. Correlation of p16 hypermethylation with p16 protein loss in sporadic gastric carcinomas. Lab Invest 2000;80:689-95.

62. Suzuki H, Itoh F, Toyota M, Kikuchi T, Kakiuchi H, Hinoda Y, et al. Distinct methylation pattern and microsatellite instability in sporadic gastric cancer. Int J Cancer 1999;83:309-13.

63. Nakajima T, Akiyama Y, Shiraishi J, Arai T, Yanagisawa Y, Ara $\mathrm{M}$, et al. Age-related hypermethylation of the hMLH1 promoter in gastric cancers. Int J Cancer 2001;94:208-11.

64. Leung WK, Yu J, Ng EK, To KF, Ma PK, Lee TL, et al. Concurrent hypermethylation of multiple tumor-related genes in gastric carcinoma and adjacent normal tissues. Cancer 2001;91:2294301.

65. Leung WK, Yu J, Ng EKW, et al. Concurrent hypermethylation of multiple tumor-related genes in gastric carcinoma and adjacent normal tissues. Cancer 2001;91:2294-301.

66. Oue N, Sentani K, Yokozaki H, Kitadai Y, Ito R, Yasui W. Promoter methylation status of the DNA repair genes hMLH1 and MGMT in gastric carcinoma and metaplastic mucosa. Pathobiology 2001;69:143-9.

67. Yasui W, Oue N, Kuniyasu H, Ito R, Tahara E, Yokozaki H. Molecular diagnosis of gastric cancer: present and future. Gastric Cancer 2001;4:113-21.

68. Toyota M, Ahuja N, Ohe-Toyota M, Herman JG, Baylin SB, Issa JP. CpG island methylator phenotype in colorectal cancer. Proc Natl Acad Sci USA 1999:96:8681-6.

69. Ohta M, Inoue H, Cotticelli MG, Kastury K, Baffa R, Palazzo J, et al. The FHIT gene, spanning the chromosome $3 p 14.2$ fragile site and renal carcinoma-associated $\mathrm{t}(3 ; 8)$ breakpoint, is abnormal in digestive tract cancers. Cell 1996;84:587-97.

70. Baffa R, Veronese ML, Santoro R, Mandes B, Palazzo JP, Rugge M, et al. Loss of FHIT expression in gastric carcinoma. Cancer Res 1998;58:4708-14.

71. Lee SH, Kim WH, Kim HK, Woo KM, Nam HS, Kim HS, et al. Altered expression of the fragile histidine triad gene in primary gastric adenocarcinomas. Biochem Biophys Res Commun 2001; 284:850-5.

72. Huiping C, Kristjansdottir S, Bergthorsson JT, Jonasson JG, Magnusson J, Egilsson V, et al. High frequency of LOH, MSI and abnormal expression of FHIT in gastric cancer. Eur J Cancer 2002;38:728-35.

73. Uchino S, Tsuda H, Noguchi M, Yokota J, Terada M, Saito T, et al. Frequent loss of heterozygosity at the DCC locus in gastric cancer. Cancer Res 1992;52:3099-102.

74. Yoshida Y, Itoh F, Endo T, Hinoda Y, Imai K. Decreased DCC mRNA expression in human gastric cancers is clinicopathologically significant. Int J Cancer 1998;79:634-9.

75. Tahara E. Molecular biology of gastric cancer. World J Surg 1995;19:484-8.

76. Tamura G. Molecular pathogenesis of adenoma and differentiated adenocarcinoma of the stomach. Pathol Int 1996;46:834-41.

77. Graziano F, Cascinu S, Staccioli MP, Catalano V, Rossi MC, Baldelli AM, et al. Potential role and chronology of abnormal expression of the Deleted in Colon Cancer (DCC) and the p53 proteins in the development of gastric cancer. BMC Cancer 2001;1:9-10.

78. Park WS, Oh RR, Park JY, Lee JH, Shin MS, Kim HS, et al. Somatic mutations of the trefoil factor family 1 gene in gastric cancer. Gastroenterology 2000;119:691-8.

79. Bossenmeyer-Pourie C, Kannan R, Ribieras S, Wendling C, Stoll I, Thim L, et al. The trefoil factor 1 participates in gastrointestinal cell differentiation by delaying G1-S phase transition and reducing apoptosis. J Cell Biol 2002;157:761-70. 
80. Nogueira AM, Machado JC, Carneiro F, Reis CA, Gott P, Sobrinho-Simoes M. Patterns of expression of trefoil peptides and mucins in gastric polyps with and without malignant transformation. J Pathol 1999;187:541-8.

81. Wu MS, Shun CT, Wang HP, Lee WJ, Wang TH, Lin JT. Loss of $\mathrm{pS} 2$ protein expression is an early event of intestinal-type gastric cancer. Jpn J Cancer Res 1998;89:278-82.

82. Hara T, Ooi A, Kobayashi M, Mai M, Yanagihara K, Nakanishi I. Amplification of c-myc, K-sam, and c-met in gastric cancers: detection by fluorescence in situ hybridization. Lab Invest 1998; 78:1143-53.

83. Carneiro F, Sobrinho-Simoes M. The prognostic significance of amplification and overexpression of c-met and c-erb B-2 in human gastric carcinomas. Cancer 2000;88:238-40.

84. Amemiya H, Kono K, Mori Y, Takahashi A, Ichihara F, Iizuka $\mathrm{H}$, et al. High frequency of c-Met expression in gastric cancers producing alpha- fetoprotein. Oncology 2000;59:145-51.

85. Zimovskii VF. Work experience of an allergology office. Voen Med Zh 1975;66-9.

86. Park WS, Oh RR, Kim YS, Park JY, Shin MS, Lee HK, et al. Absence of mutations in the kinase domain of the Met gene and frequent expression of Met and $\mathrm{HGF} / \mathrm{SF}$ protein in primary gastric carcinomas. APMIS 2000;108:195-200.

87. Ponzetto C, Giordano S, Peverali F, Della Valle G, Abate ML, Vaula $\mathrm{G}$, et al. c-met is amplified but not mutated in a cell line with an activated met tyrosine kinase. Oncogene 1991;6:5539.

88. Yu J, Miehlke S, Ebert MP, Hoffmann J, Breidert M, Alpen B, et al. Frequency of TPR-MET rearrangement in patients with gastric carcinoma and in first-degree relatives. Cancer 2000; 88:1801-5

89. Ross JS, McKenna BJ. The HER-2/neu oncogene in tumors of the gastrointestinal tract. Cancer Invest 2001;19:554-68.

90. Mizutani T, Onda M, Tokunaga A, Yamanaka N, Sugisaki Y. Relationship of C-erbB-2 protein expression and gene amplification to invasion and metastasis in human gastric cancer. Cancer 1993;72:2083-8.

91. Allgayer H, Babic R, Gruetzner KU, Tarabichi A, Schildberg FW, Heiss MM. C-erbB-2 is of independent prognostic relevance in gastric cancer and is associated with the expression of tumor-associated protease systems. J Clin Oncol 2000;18:22019.

92. Wang YL, Sheu BS, Yang HB, Lin PW, Chang YC. Overexpression of c-erb-B2 proteins in tumor and non-tumor parts of gastric adenocarcinoma-emphasis on its relation to $H$. pylori infection and clinicohistological characteristics. Hepatogastroenterology 2002;49:1172-6.

93. Tateishi M, Toda T, Minamisono Y, Nagasaki S. Clinicopathological significance of c-erbB-2 protein expression in human gastric carcinoma. J Surg Oncol 1992;49:209-12.

94. Rajevic U, Juvan R, Gazvoda B, Repse S, Komel R. Assessment of differential expression of oncogenes in gastric adenocarcinoma by fluorescent multiplex RT-PCR assay. Pflugers Arch 2001;442(6 Suppl 1):R190-2.

95. Yu J, Miehlke S, Ebert MP, Szokodi D, Wehvnignh B, Malfertheiner P, et al. Expression of cyclin genes in human gastric cancer and in first degree relatives. Chin Med J (Engl) 2002;115:710-5.

96. Kozma L, Kiss I, Hajdu J, Szentkereszty Z, Szakall S, Ember I. $\mathrm{C}$-myc amplification and cluster analysis in human gastric carcinoma. Anticancer Res 2001;21:707-10.

97. Katoh M. WNT2 and human gastrointestinal cancer (review). Int J Mol Med 2003;12:811-6.

98. Czerniak B, Herz F, Gorczyca W, Koss LG. Expression of ras oncogene p21 protein in early gastric carcinoma and adjacent gastric epithelia. Cancer 1989;64:1467-73.

99. Ohuchi N, Hand PH, Merlo G, Fujita J, Mariani-Costantini R, Thor A, et al. Enhanced expression of c-Ha-ras p21 in human stomach adenocarcinomas defined by immunoassays using monoclonal antibodies and in situ hybridization. Cancer Res 1987;47:1413-20.

100. Yamamoto T, Hattori T, Tahara E. Interaction between transforming growth factor alpha and c-Ha-ras p21 in progression of human gastric carcinoma. Pathol Res Pract 1988;183:6639 .

101. Spandidos DA, Karayiannis M, Yiagnisis M, Papadinitrion K, Field JK. Immunohistochemical analysis of the expression of the c-myc oncoprotein in human stomach cancers. Digestion 1991; 50:127-34.

102. Ninomiya I, Yonemura Y, Matsumoto H, Sugiyama K, Kamata $\mathrm{T}$, Miwa K, et al. Expression of c-myc gene product in gastric carcinoma. Oncology 1991;48:149-53.

103. Miyachi K, Fujita M, Tanaka N, Sasaki K, Sunagawa M. Correlation between telomerase activity and telomeric-repeat binding factors in gastric cancer. J Exp Clin Cancer Res 2002;21:269-75.

104. Yang SM, Fang DC, Luo YH, Lu R, Battle PD, Liu WW. Alterations of telomerase activity and terminal restriction fragment in gastric cancer and its premalignant lesions. J Gastroenterol Hepatol 2001;16:876-82.

105. Krupp G, Bonatz G, Parwaresch R. Telomerase, immortality and cancer. Biotechnol Annu Rev 2000;6:103-40.

106. Tahara E, Kuniyasu H, Yasui W, Yokozaki H. Gene alterations in intestinal metaplasia and gastric cancer. Eur J Gastroenterol Hepatol 1994:6 (Suppl 1):S97-101.

107. Kakeji Y, Maehara Y, Koga T, Shibahara K, Kabashima A, Tokunaga E, et al. Gastric cancer with high telomerase activity shows rapid development and invasiveness. Oncol Rep 2001; 8:107-10.

108. Jong HS, Park YI, Kim S, Sohn JH, Kang SH, Song SH, et al. Upregulation of human telomerase catalytic subunit during gastric carcinogenesis. Cancer 1999;86:559-65.

109. Xie K, Huang S. Regulation of cancer metastasis by tumorassociated stress factors. Clin Exp Metastasis 2003;20:31-43.

110. Filipe MI, Osborn M, Linehan J, Sanidas E, Brito MJ, Jankowski J. Expression of transforming growth factor alpha, epidermal growth factor receptor and epidermal growth factor in precursor lesions to gastric carcinoma. Br J Cancer 1995;71:30-6.

111. Naef M, Yokoyama M, Friess H, Buchler MW, Korc M. Co-expression of heparin-binding EGF-like growth factor and related peptides in human gastric carcinoma. Int J Cancer 1996; 66:315-21.

112. Hiyama T, Tanaka S, Haruma K, Chayama K. The roles of $H$. pylori infection and K-ras gene mutation in gastric carcinogenesis. Nippon Rinsho (Jpn J Clin Med) 2003;61:46-9.

113. Brown LF, Berse B, Jackman RW, Tognazzi K, Manseau EJ, Senger DR, et al. Expression of vascular permeability factor (vascular endothelial growth factor) and its receptors in adenocarcinomas of the gastrointestinal tract. Cancer Res 1993;53: 4727-35.

114. Ichikura T, Tomimatsu S, Ohkura E, Mochizuki H. Prognostic significance of the expression of vascular endothelial growth factor (VEGF) and VEGF-C in gastric carcinoma. J Surg Oncol 2001;78:132-7.

115. Wang L, Wei D, Huang S, Peng Z, Le X, Wu TT, et al. Transcription factor $\mathrm{Sp} 1$ expression is a significant predictor of survival in human gastric cancer. Clin Cancer Res 2003;9:6371-80.

116. Iida S, Katoh O, Tokunaga A, Terada M. Expression of fibroblast growth factor gene family and its receptor gene family in the human upper gastrointestinal tract. Biochem Biophys Res Commun 1994;199:1113-9.

117. Ueki T, Koji T, Tamiya S, Nakane PK, Tsuneyoshi M. Expression of basic fibroblast growth factor and fibroblast growth factor receptor in advanced gastric carcinoma. J Pathol 1995;177:35361.

118. Chung CK, Antoniades HN. Expression of c-sis/platelet-derived growth factor $\mathrm{B}$, insulin-like growth factor I, and transforming growth factor alpha messenger RNAs and their respective receptor messenger RNAs in primary human gastric carcinomas: in 
vivo studies with in situ hybridization and immunocytochemistry. Cancer Res 1992;52:3453-9.

119. Guo YS, Beauchamp RD, Jin GF, Townsend CM Jr, Thompson JC. Insulinlike growth factor-binding protein modulates the growth response to insulinlike growth factor 1 by human gastric cancer cells. Gastroenterology 1993;104:1595-604.

120. Wang S, Souza RF, Kong D, Yin J, Smolinski KN, Zou TT, et al. Deficient transforming growth factor-beta1 activation and excessive insulin-like growth factor II (IGFII) expression in IGFII receptor-mutant tumors. Cancer Res 1997;57:2543-6.

121. Hirayama D, Fujimori T, Satonaka K, Nakamura T, Kitazawa S, Horio M, et al. Immunohistochemical study of epidermal growth factor and transforming growth factor-beta in the penetrating type of early gastric cancer. Hum Pathol 1992;23: 681-5.

122. Ebert MP, Yu J, Miehlke S, Fei G, Lendeckel U, Ridwelski K, et al. Expression of transforming growth factor beta-1 in gastric cancer and in the gastric mucosa of first-degree relatives of patients with gastric cancer. Br J Cancer 2000;82:1795800.

123. Tomimatsu S, Ichikura T, Mochizuki H. Significant correlation between expression of interleukin-1alpha and liver metastasis in gastric carcinoma. Cancer 2001;91:1272-6.

124. El-Omar EM, Carrington M, Chow WH, McColl KE, Bream JH, Young HA, et al. Interleukin-1 polymorphisms associated with increased risk of gastric cancer [published erratum appears in Nature 2001;412:99]. Nature 2000;404:398-402.

125. Crabtree JE, Wyatt JI, Trejdosiewicz LK, Peichl P, Nichols PH, Ramsay N, et al. Interleukin-8 expression in Helicobacter pylori infected, normal, and neoplastic gastroduodenal mucosa. J Clin Pathol 1994;47:61-6.

126. Kitadai Y, Haruma K, Sumii K, Yamamoto S, Ue T, Yokozaki $\mathrm{H}$, et al. Expression of interleukin-8 correlates with vascularity in human gastric carcinomas. Am J Pathol 1998;152:93-100.

127. Kitadai Y, Haruma K, Mukaida N, Ohmoto Y, Matsutani N, Yasui $\mathrm{W}$, et al. Regulation of disease-progression genes in human gastric carcinoma cells by interleukin 8. Clin Cancer Res 2000;6:2735-40.

128. Shi Q, Le X, Wang B, Abbruzzese JL, Xiong Q, He Y, et al. Regulation of vascular endothelial growth factor expression by acidosis in human cancer cells. Oncogene 2001;20:3751-6.

129. Shweiki D, Itin A, Soffer D, Keshet E. Vascular endothelial growth factor induced by hypoxia may mediate hypoxia-initiated angiogenesis. Nature 1992;359:843-5.

130. Xie K. Interleukin-8 and human cancer biology. Cytokine Growth Factor Rev 2001;12:375-91.

131. Neufeld G, Cohen T, Gengrinovitch S, Poltorak Z.Vascular endothelial growth factor (VEGF) and its receptors. FASEB J 1999;13:9-22.

132. Shi Q, Le X, Peng Z, Tang H, Xiong Q, Wang B, et al. Constitutive Sp1 activity is essential for differential constitutive expression of vascular endothelial growth factor in human pancreatic adenocarcinoma. Cancer Res 2001;61:4143-54.

133. Rak J, Filmus J, Finkenzeller G, Grugel S, Marme D, Kerbel RS. Oncogenes as inducers of tumor angiogenesis. Cancer Metastasis Rev 1995;14:263-77.

134. Tischer E, Mitchell R, Hartman T, Silva M, Gospodarowicz D, Fiddes JC, et al. The human gene for vascular endothelial growth factor. Multiple protein forms are encoded through alternative exon splicing. J Biol Chem 1991;266:11947-54.

135. Wei D, Le X, Zheng L, Wang L, Frey JA, Gao AC, et al. Stat3 activation regulates the expression of vascular endothelial growth factor and human pancreatic cancer angiogenesis and metastasis. Oncogene 2003;22:319-29.

136. Le X, Shi Q, Wang B, Xiong Q, Qian C-N, Peng Z, et al. Molecular regulation of constitutive expression of interleukin-8 in human pancreatic adenocarcinoma. J Interferon Cytokine Res 2000;20:1532-40.

137. Raff M. Cell suicide for beginners.Nature 1998;396:199-22.
138. Klein RF, Vollmers HP, Müller-Hermelink HK. Different expression of bcl-2 in diffuse and intestinal type stomach carcinomas. Oncol Rep 1994;69:943-6.

139. Vollmers HP, Dammrich J, Hensel F, Ribbert H, MeyerBahlburg A, Ufken-Gaul T, et al. Differential expression of apoptosis receptors on diffuse and intestinal type stomach carcinoma. Cancer 1997;79:433-40.

140. Ikeda M, Shomori K, Endo K, Makino T, Matsuura T, Ito H. Frequent occurrence of apoptosis is an early event in the oncogenesis of human gastric carcinoma. Virchows Arch 1998;432: 43-7.

141. Ikeguchi M, Cai J, Yamane N, Maeta M, Kaibara N. Clinical significance of spontaneous apoptosis in advanced gastric adenocarcinoma. Cancer 1999:85:2329-35.

142. Mijic A, Ferencic Z, Belicza M, Fucic A, Sevic SR, Sarcevic B, et al. Apoptosis in human gastric polyps and adenocarcinomas: a stereological analysis. Hepatogastroenterology 1998;45:68490.

143. Koshida Y, Saegusa M, Okayasu I. Apoptotosis, cell proliferation and expression of $\mathrm{Bcl}-2$ and $\mathrm{Bax}$ in gastric carcinomas: immunohistochemical and clinicopathological study. Br J Cancer 1997;75:367-73.

144. Ishii HH, Gobe GC, Pan W, Yoneyama J, Ebihara Y. Apoptosis and cell proliferation in the development of gastric carcinomas: associations with $\mathrm{c}$-myc and p53 protein expression. J Gastroenterol Hepatol 2002;17:966-72.

145. Akama Y, Yasui H, Yokozaki H, Kuniyasu K, Kitahara T, Ishikawa W, et al. Frequent amplification of the cyclin $\mathrm{E}$ gene in human gastric carcinomas. Jpn J Cancer Res 1995;86:617-21.

146. Muller W, Noguchi T, Wirtz HC, Hommel G, Gabbert HE. Expression of cell-cycle regulatory proteins cyclin D1, cyclin E, and their inhibitor p21 WAF1/CIP1 in gastric cancer. J Pathol 1999;189:186-93.

147. Yasui W, Kudo Y, Semba S, Yokozaki H, Tahara E. Reduced expression of cyclin-dependent kinase inhibitor p27Kip1 is associated with advanced stage and invasiveness of gastric carcinomas. Jpn J Cancer Res 1997;88:625-9.

148. Joo YE, Rew JS, Choi SK, Bom HS, Park CS, Kim SJ. Expression of e-cadherin and catenins in early gastric cancer. J Clin Gastroenterol 2002;35:35-42.

149. Takeichi M. Cadherin cell adhesion receptors as a morphogenetic regulator. Science 1991;251:1451-7.

150. Mingchao, Devereux TR, Stockton P, Sun K, Sills RC, Clayton $\mathrm{N}$, et al. Loss of E-cadherin expression in gastric intestinal metaplasia and later stage p53 altered expression in gastric carcinogenesis. Exp Toxicol Pathol 2001;53:237-46.

151. Tanaka M, Kitajima Y, Edakuni G, Sato S, Miyazaki K. Abnormal expression of E-cadherin and beta-catenin may be a molecular marker of submucosal invasion and lymph node metastasis in early gastric cancer. Br J Surg 2002;89:236-44.

152. Oda T, Kanai Y, Oyama T, Yoshiura K, Shimoyama Y, Birchmeier W, et al. E-Cadherin gene mutations in human gastric carcinoma cell lines. Proc Natl Acad Sci USA 1994;91:185862.

153. Becker KF, Atkinson MJ, Reich U, Becker I, Nekarda H, Siewert JR, et al. E-cadherin gene mutations provide clues to diffuse type gastric carcinomas. Cancer Res 1994;54:3845-52.

154. Handschuh G, Candidus S, Luber B, Reich U, Schott C, Oswald $\mathrm{S}$, et al. Tumor-associated E-cadherin mutations alter cellular morphology, decrease cellular adhesion and increase cellular motility. Oncogenetics 1999;18:4301-12.

155. Schwarz A. Preventive gastrectomy in patients with gastric cancer risk due to genetic alterations of the E-cadherin gene defect. Langenbecks Arch Surg 2003;388:27-32.

156. Fitzgerald RC, Caldas C. E-cadherin mutations and hereditary gastric cancer: prevention by resection? Dig Dis 2002;20:23-31.

157. Chun YS, Lindor NM, Smyrk TC, Petersen BT, Burgart LJ, Guilford PJ, et al. Germline E-cadherin gene mutations: is prophylactic total gastrectomy indicated? Cancer 2001;92:181-7. 
158. el-Rifai W, Powell SM. Molecular and biologic basis of upper gastrointestinal malignancy. Gastric carcinoma. Surg Oncol Clin North Am 2002;11:273-91, viii.

159. Nathan C. Nitric oxide as a secretory product of mammalian cells. FASEB J 1992;6:3051-64.

160. Moncada S, Higgs A. The L-arginine-nitric oxide pathway. N Engl J Med 1993;329:2002-12.

161. Ambs S, Hussain SP, Harris CC. Interactive effects of nitric oxide and the p53 tumor suppressor gene in carcinogenesis and tumor progression. FASEB J 1997;11:443-8.

162. Fukumura D, Jain RK. Role of nitric oxide in angiogenesis and microcirculation in tumors. Cancer Metastasis Rev 1998;17:77-89.

163. Tamir S, Tannenbaum SR. The role of nitric oxide (NO) in the carcinogenic process. Biochim Biophys Acta 1996;1288:F31-6.

164. Wink DA, Vodovotz Y, Laval J, Laval F, Dewhirst MW, Mitchell JB. The multifaceted roles of nitric oxide in cancer. Carcinogenesis 1998;19:711-21.

165. Wang B, Wei D, Crum VE, Richardson EL, Luo Y, Shi Q, et al. A novel model system for studying the double-edged roles of nitric oxide production in pancreatic cancer growth and metastasis. Oncogene 2003;22:1771-82.

166. Xie K, Huang S. Contribution of nitric oxide-mediated apoptosis to cancer metastasis inefficiency. Free Radic Biol Med 2003; 34:969-86.

167. Radomski MK, Jenkins DC, Holmes L, Moncada S. Human colorectal adenocarcinoma cells: differential nitric oxide synthesis determines their ability to aggregate platelets. Cancer Res 1991;51:6073-8.

168. Xie K, Wang Y, Huang S, Xu L, Bielenberg D, Salas T, et al. Nitric oxide-mediated apoptosis of K-1735 melanoma cells is associated with downregulation of Bcl-2. Oncogene 1997;15:7719.

169. Shi Q, Huang S, Jiang W, Kutach LS, Ananthaswamy HN, Xie K. Direct correlation between nitric oxide synthase II inducibility and metastatic ability of UV-2237 murine fibrosarcoma cells carrying mutant p53. Cancer Res 1999;59:2072-5.

170. Hibbs JB Jr, Taintor RR, Vavrin Z. Macrophage cytotoxicity: role for L-arginine deiminase and imino nitrogen oxidation to nitrite. Science 1987;235:473-6.

171. Thomsen LL, Miles DW, Happerfield L, Bobrow LG, Knowles RG, Moncada S. Nitric oxide synthase activity in human breast cancer. Br J Cancer 1995;72:41-4.

172. Cobbs CS, Brenman JE, Aldape KD, Bredt DS, Israel MA. Expression of nitric oxide synthase in human central nervous system tumors. Cancer Res 1995;55:727-30.

173. Leibovich SJ, Polverini PJ, Fong TW, Harlow LA, Koch AE. Production of angiogenic activity by human monocytes requires an L-arginine/nitric oxide-synthase-dependent effector mechanism. Proc Natl Acad Sci USA 1994;91:4190-4.

174. Schmidt HH, Walter U. NO at work. Cell 1994;78:919-25.

175. Jenkins DC, Charles IG, Thomsen LL, Moss DW, Holmes LS, Baylis SA, et al. Roles of nitric oxide in tumor growth. Proc Natl Acad Sci USA 1995;92:4392-6.

176. Leung DW, Cachianes G, Kuang WJ, Goeddel DV, Ferrara N. Vascular endothelial growth factor is a secreted angiogenic mitogen. Science 1989;246:1306-9.

177. Senger DR, Perruzzi CA, Feder J, Dvorak HF. A highly conserved vascular permeability factor secreted by a variety of human and rodent tumor cell lines. Cancer Res 1986;46:5629-32.

178. Rajnakova A, Moochhala S, Goh PM, Ngoi S. Expression of nitric oxide synthase, cyclooxygenase, and p53 in different stages of human gastric cancer. Cancer Lett 2001;172:177-85.

179. Rajnakova A, Goh PM, Chan ST, Ngoi SS, Alponat A, Moochhala S. Expression of differential nitric oxide synthase isoforms in human normal gastric mucosa and gastric cancer tissue. Carcinogenesis 1997;18:1841-5.

180. Koh E, Noh SH, Lee YD, Lee HY, Han JW, Lee HW, et al. Differential expression of nitric oxide synthase in human stomach cancer. Cancer Lett 1999;146:173-80.
181. Goto T, Haruma K, Kitadai Y, Ito M, Yoshihara M, Sumii K, et al. Enhanced expression of inducible nitric oxide synthase and nitrotyrosine in gastric mucosa of gastric cancer patients. Clin Cancer Res 1999;5:1411-5.

182. Holian O, Wahid S, Atten MJ, Attar BM. Inhibition of gastric cancer cell proliferation by resveratrol: role of nitric oxide. Am J Physiol Gastrointest Liver Physiol 2002;282:G809-16.

183. Feng CW, Wang LD, Jiao LH, Liu B, Zheng S, Xie XJ. Expression of p53, inducible nitric oxide synthase and vascular endothelial growth factor in gastric precancerous and cancerous lesions: correlation with clinical features. BMC Cancer 2002;2:8.

184. Khare PD, Liao S, Hirose Y, Kuroki M, Fujimura S, Yamauchi $\mathrm{Y}$, et al. Tumor growth suppression by a retroviral vector displaying $\mathrm{scFv}$ antibody to CEA and carrying the iNOS gene. Anticancer Res 2002;22:2443-6.

185. Rajnakova A, Moochhala S, Goh PM, Ngoi S. Expression of nitric oxide synthase, cyclooxygenase, and p53 in different stages of human gastric cancer. Cancer Lett 2001;172:17785 .

186. Van Rees BP, Saukkonen K, Ristimaki A, Polkowski W, Tytgat GN, Drillenburg P, et al. Cyclooxygenase-2 expression during carcinogenesis in the human stomach. J Pathol 2002;196:1719.

187. Van Rees BP, Ristimäki A. Cyclooxygenase-2 in carcinogenesis of the gastrointestinal tract. Scand J Gastroenterol 2001;36:897903.

188. Lim HY, Joo HJ, Choi JH, Yi JW, Yang MS, Cho DY, et al. Increased expression of cyclooxygenase-2 protein in human gastric carcinoma. Clin Cancer Res 2000;6:519-25.

189. Saukkonen K, Nieminen O, van Rees B, Vilkki S, Harkonen M, Juhola M, et al. Expression of cyclooxygenase-2 in dysplasia of the stomach and in intestinal-type gastric adenocarcinoma. Clin Cancer Res 2001;7:1923-31.

190. Lee TL, Leung WK, Lau JY, Tong JH, Ng EK, Chan FK, et al. Inverse association between cyclooxygenase-2 overexpression and microsatellite instability in gastric cancer. Cancer Lett 2001;168:133-40.

191. Murata H, Kawano S, Tsuji S, Tsuji M, Sawaoka H, Kimura Y, et al. Cyclooxygenase-2 overexpression enhances lymphatic invasion and metastasis in human gastric carcinoma. Am J Gastroenterol 1999;94:451-5.

192. Song SH, Jong HS, Choi HH, Inoue H, Tanabe T, Kim NK, et al. Transcriptional silencing of cyclooxygenase-2 by hypermethylation of the $5^{\prime} \mathrm{CpG}$ island in human gastric carcinoma cells. Cancer Res 2001;61:4628-35.

193. Kim H, Lim JW, Kim KH. Helicobacter pylori-induced expression of interleukin-8 and cyclooxygenase-2 in AGS gastric epithelial cells: mediation by nuclear factor-kappaB. Scand J Gastroenterol 2001;36:706-16.

194. Akhtar M, Cheng Y, Magno RM, Ashktorab H, Smoot DT, Meltzer SJ, et al. Promoter methylation regulates Helicobacter pylori-stimulated cyclooxygenase-2 expression in gastric epithelial cells. Cancer Res 2001;61:2399-403.

195. McCarthy CJ, Crofford LJ, Greenson J, Scheiman JM. Cyclooxygenase-2 expression in gastric antral mucosa before and after eradication of Helicobacter pylori infection. Am J Gastroenterol 1999;94:1218-23.

196. Fukuda Y, Kurihara N, Imoto I, Yasui K, Yoshida M, Yanagihara $\mathrm{K}$, et al. CD44 is a potential target of amplification within the 11p13 amplicon detected in gastric cancer cell lines. Genes Chromosomes Cancer 2000;29:315-24.

197. Iizuka N, Tangoku A, Hazama S, Yoshino S, Mori N, Oka M. $\mathrm{Nm} 23-\mathrm{H} 1$ gene as a molecular switch between the free-floating and adherent states of gastric cancer cells. Cancer Lett 2001; 174:65-71.

198. Kawasaki K, Hayashi Y, Wang Y, Suzuki S, Morita Y, Nakamura T, et al. Expression of urokinase-type plasminogen activator receptor and plasminogen activator inhibitor-1 in gastric cancer. J Gastroenterol Hepatol 1998;13:936-44. 
199. Karlsson KA. The human gastric colonizer Helicobacter pylori: a challenge for host-parasite glycobiology. Glycobiology 2000;10: 761-71.

200. Almeida R, Silva E, Santos-Silva F, Silberg DG, Wang J, De Bolos $\mathrm{C}$, et al. Expression of intestine-specific transcription factors, CDX1 and CDX2, in intestinal metaplasia and gastric carcinomas. J Pathol 2003;199:36-40.

201. Yu Y, Zhang YC, Zhang WZ, Shen LS, Hertzog P, Wilson TJ, et al. Ets1 as a marker of malignant potential in gastric carcinoma. World J Gastroenterol 2003;9:2154-9.

202. Tsutsumi S, Kuwano H, Asao T, Nagashima K, Shimura T, Mochiki E. Expression of Ets-1 angiogenesis-related protein in gastric cancer. Cancer Lett 2000;160:45-50.

203. Sasaki N, Morisaki T, Hashizume K, Yao T, Tsuneyoshi M, Noshiro H, et al. Nuclear factor-kappaB p65 (RelA) transcription factor is constitutively activated in human gastric carcinoma tissue. Clin Cancer Res 2001;7:4136-42.

204. Naito Y, Yoshikawa T. Molecular and cellular mechanisms involved in Helicobacter pylori-induced inflammation and oxidative stress. Free Radic Biol Med 2002;33:323-36.

205. Moss SF, Calam J, Agarwal B, Wang S, Holt PG. Induction of gastric epithelial apoptosis by Helicobacter pylori. Gut 1996;38: 498-501.

206. Jones NL, Shannon PT, Cutz E, Yeger H, Sherman PM. Increase in proliferation and apoptosis of gastric epithelial cells early in the natural history of Helicobacter pylori infection. Am J Pathol 1997;151:1695-703.

207. Fan XG, Kelleher D, Fan XJ, Xia HX, Keeling PW. Helicobacter pylori increases proliferation of gastric epithelial cells. Gut 1996;38:19-22.

208. Terres AM, Pajares JM, OToole D, Ahern S, Kelleher D. H. pylori infection is associated with downregulation of E-cadherin, a molecule involved in epithelial cell adhesion and proliferation control. J Clin Pathol 1998;51:410-2.

209. Yu J, Ebert MP, Miehlke S, Rost H, Lendeckel U, Leodolter A, et al. Alpha-catenin expression is decreased in human gastric cancers and in the gastric mucosa of first degree relatives. Gut 2000;46:639-44.

210. Shibata A, Parsonnet J, Longacre TA, Garcia MI, Puligandla B, Davis RE, et al. CagA status of Helicobacter pylori infection and p53 gene mutations in gastric adenocarcinoma. Carcinogenesis 2002;23:419-24

211. Kubicka S, Claas C, Staab S, Kuhnel F, Zender L, Trautwein C, et al. p53 mutation pattern and expression of c-erbB2 and c-met in gastric cancer: relation to histological subtypes, Helicobacter pylori infection, and prognosis. Dig Dis Sci 2002;47:114-21.

212. Wang J, Chi DS, Kalin GB, Sosinski C, Miller LE, Burja I, et al. Helicobacter pylori infection and oncogene expressions in gastric carcinoma and its precursor lesions. Dig Dis Sci 2002;47:107-13.

213. Wu MS, Shun CT, Wang HP, Sheu JC, Lee WJ, Wang TH, et al. Genetic alterations in gastric cancer: relation to histological subtypes, tumour stage, and Helicobacter pylori infection. Gastroenterology 1997;112:1457-65.

214. Blok P, Craanen ME, Offerhaus GJ, Dekker W, Kuipers EJ, Meuwissen SG, et al. Molecular alterations in early gastric carcinomas. No apparent correlation with Helicobacter pylori status. Am J Clin Pathol 1999;111:241-7.

215. Lin ST, Wu MS, Shun CT, Lee WJ, Wang JT, Wang TH, et al. Microsatellite instability in gastric carcinoma with special references to histopathology and cancer stages. Eur J Cancer 1995; 31A:1879-82.

216. Churin Y, Al-Ghoul L, Kepp O, Meyer TF, Birchmeier W, Naumann M. Helicobacter pylori CagA protein targets the c-Met receptor and enhances the motogenic response. J Cell Biol 2003;161:249-55.

217. Konturek PC, Konturek SJ, Pierzchalski P, Bielanski W, Duda A, Marlicz K, et al. Cancerogenesis in Helicobacter pylori infected stomach-role of growth factors, apoptosis and cyclooxygenases. Med Sci Monit 2001;7:1092-107.
218. Konturek PC, Konturek SJ, Bielanski W, Karczewska E, Pierzchalski P, Duda A, et al. Role of gastrin in gastric cancerogenesis in Helicobacter pylori infected humans. J Physiol Pharmacol 1999;50:857-73.

219. Odenbreit S, Puls J, Sedlmaier B, Gerland E, Fischer W, Haas R. Translocation of Helicobacter pylori CagA into gastric epithelial cells by type IV secretion. Science 2000;287:1497-500.

220. Semba S, Yokozaki H, Yamamoto S, Yasui W, Tahara E. Microsatellite instability in precancerous lesions and adenocarcinomas of the stomach. Cancer 1996;77(8 Suppl):1620-7.

221. Fleisher AS, Esteller M, Tamura G, Rashid A, Stine OC, Yin J, et al. Hypermethylation of the hMLH1 gene promoter is associated with microsatellite instability in early human gastric neoplasia. Oncogene 2001;20:329-35.

222. Guilford P, Hopkins J, Harraway J, McLeod M, McLeod N, Harawira $\mathrm{P}$, et al. E-cadherin germline mutations in familial gastric cancer. Nature 1998;392:402-5.

223. Caldas C, Carneiro F, Lynch HT, Yokota J, Wiesner GL, Powell SM, et al. Familial gastric cancer: overview and guidelines for management. J Med Genet 1999;36:873-80.

224. Shin Y, Kim IJ, Kang HC, Park JH, Park HR, Park HW, et al. The E-cadherin $-347 \mathrm{G} \rightarrow \mathrm{GA}$ promoter polymorphism and its effect on transcriptional regulation. Carcinogenesis 2004; DOI 10.1093/carcin/bgh073.

225. Oliveira C, Bruin JD J, Nabais S, Ligtenberg M, Moutinho C, Nagengast FM, et al. Intragenic deletion of CDH1 as the inactivating mechanism of the wild-type allele in an HDGC tumour. Oncogene 2004;23:2236-40.

226. Ruzzo A, Graziano F, Costagliola A, Arduini F, Testa E, Bearzi I, et al. The G/A nucleotide change at cDNA position 2494 in the E-cadherin gene (CDH1): analysis in Italian patients. Tumour Biol 2003;24:147-50.

227. Suriano G, Oliveira MJ, Huntsman D, Mateus AR, Ferreira P, Casares F, et al. E-cadherin germline missense mutations and cell phenotype: evidence for the independence of cell invasion on the motile capabilities of the cells. Hum Mol Genet 2003;12: 3007-16.

228. Sanz-Ortega J, Steinberg SM, Moro E, Saez M, Lopez JA, Sierra $\mathrm{E}$, et al. Comparative study of tumor angiogenesis and immunohistochemistry for p53, c-ErbB2, c-myc and EGFr as prognostic factors in gastric cancer. Histol Histopathol 2000;15:45562 .

229. Guilford PJ, Hopkins JB, Grady WM, Maarkowitz SD, Willis J, Lynch H, et al. E-cadherin germline mutations define an inherited cancer syndrome dominated by diffuse gastric cancer. Hum Mutat 1999;14:2249-554.

230. Yonemura Y, Ninomiya I, Yamaguchi A, Fushida S, Kimura H, Ohoyama S, et al. Evaluation of immunoreactivity for erbB-2 protein as a marker of poor short term prognosis in gastric cancer. Cancer Res 1991;51:1034-8.

231. Simpson AJ, Caballero OL, Pena SD. Microsatellite instability as a tool for the classification of gastric cancer. Trends Mol Med 2001;7:76-80

232. Hiyama T, Tanaka S, Kitadai Y, Ito M, Sumii M, Yoshihara M, et al. p53 Codon 72 polymorphism in gastric cancer susceptibility in patients with Helicobacter pylori-associated chronic gastritis. Int J Cancer 2002;100:304-8.

233. Okusa Y, Ichikura T, Mochizuki H. Prognostic impact of stromal cell-derived urokinase-type plasminogen activator in gastric carcinoma. Cancer 1999;85:1033-8.

234. Levitzki A, Gazit A. Tyrosine kinase inhibition: an approach to drug development. Science 1995;267:1782-8.

235. Vollmers HP, Zimmermann U, Krenn V, Timmermann W, Illert B, Hensel F, et al. Adjuvant therapy for gastric adenocarcinoma with the apoptosis-inducing human monoclonal antibody SC-1: first clinical and histopathological results. Oncol Rep 1998;5: 549-52.

236. Sasaki S, Tsujisaki M, Jinnohara T, Ishida T, Sekiya M, Adachi $\mathrm{M}$, et al. Human tumor growth suppression by apoptosis induced 
with anti-ErbB-2 chimeric monoclonal antibody. Jpn J Cancer Res 1998;89:562-70.

237. Hensel F, Hermann R, Brandlein S, Krenn V, Schmausser B, Geis S, et al. Regulation of the new coexpressed CD55 (decayaccelerating factor) receptor on stomach carcinoma cells involved in antibody SC-1-induced apoptosis. Lab Invest 2001;81: 1553-63.

238. Becker KF, Kremmer E, Eulitz M, Becker I, Handschuh G, Schuhmacher C, et al. Analysis of E-cadherin in diffuse-type gastric cancer using a mutation-specific monoclonal antibody. Am J Pathol 1999;155:1803-9.

239. Steele RJ, Lane DP. Gene therapy for gastric cancer: problems and prospects. Surg Oncol 2000;9:13-6.

240. Boussioutas A, Taupin D. Towards a molecular approach to gastric cancer management. Intern Med J 2001;31:296-303.

241. Suarez-Quian CA, Godstein SR, Pohida T, Smith PD, Peterson JI, Wellner E, et al. Laser capture microdissection of single cells from complex tissues. Biotechniques 1999;26:328-35.
242. Sieben NL, ter Haar NT, Cornelisse CJ, Fleuren GJ, CletonJansen AM. PCR artifacts in LOH and MSI analysis of microdissected tumor cells. Hum Pathol 2000;31:1414-9.

243. Mori M, Mimori K, Yoshikawa Y, Shibuta K, Utsunomiya T, Sadanaga N, et al. Analysis of the gene-expression profile regarding the progression of human gastric carcinoma. Surgery 2002;131(1 Suppl):S39-47.

244. Hippo Y, Taniguchi H, Tsutsumi S, Machida N, Chong JM, Fukayama M, et al. Global gene expression analysis of gastric cancer by oligonucleotide microarrays. Cancer Res 2002;62:23340.

245. Boussioutas A, Li H, Liu J, Waring P, Lade S, Holloway AJ, et al. Distinctive patterns of gene expression in premalignant gastric mucosa and gastric cancer. Cancer Res 2003;63:256977. 